Article

\title{
Sedimentological, Mineralogical and Geochemical Features of Late Quaternary Sediment Profiles from the Southern Tuscany Hg Mercury District (Italy): Evidence for the Presence of Pre-Industrial Mercury and Arsenic Concentrations
}

\author{
Francesca Pasquetti ${ }^{1, *}$, Orlando Vaselli ${ }^{2,3}$, Giovanni Zanchetta ${ }^{1,4,5}$, Barbara Nisi ${ }^{3}$, \\ Marco Lezzerini ${ }^{1}$ (D), Monica Bini ${ }^{1,5,6}$ and Daniela Mele ${ }^{7}$ (D) \\ 1 Department of Earth Sciences, University of Pisa, Via S. Maria 53, 56126 Pisa, Italy; \\ giovanni.zanchetta@unipi.it (G.Z.); marco.lezzerini@unipi.it (M.L.); monica.bini@unipi.it (M.B.) \\ 2 Department of Earth Sciences, University of Florence, Via G. La Pira 4, 50121 Florence, Italy; \\ orlando.vaselli@unifi.it \\ 3 IGG-CNR, Institute of Geosciences and Earth Resources, Via G. La Pira 4, 50121 Florence, Italy; \\ barbara.nisi@igg.cnr.it \\ 4 IGAG-CNR, Institute of Environmental Geology and Geoengineering, Via Salaria km 29,300, Monterotondo, \\ 00015 Rome, Italy \\ 5 CIRSEC, Centre of Climatic Change Impact, Via del Borghetto 80, 56124 Pisa, Italy \\ 6 INGV, Isituto Nazionale di Geofisica e Vulcanologia, Via Cesare Battisti 53, 56125 Pisa, Italy \\ 7 Department of Earth and Geoenvironmental Sciences, University of Bari, Via Orabona 4, 70125 Bari, Italy; \\ daniela.mele@uniba.it \\ * Correspondence: francesca.pasquetti@dst.unipi.it
}

Received: 16 June 2020; Accepted: 10 July 2020; Published: 14 July 2020

check for updates

\begin{abstract}
Southern Tuscany (Italy) is an important metallogenic district that hosts relevant S-polymetallic deposits that have intensely been exploited for centuries. Consequently, potential toxic elements, such as $\mathrm{Hg}$ and As, are widely distributed in the surrounding environment. In this paper, an extensive sedimentological, mineralogical and geochemical study of two Late Quaternary sediment profiles, partially outcropping along the coast of southern Tuscany (Ansedonia area), was carried out to evaluate the contents and mobility of $\mathrm{Hg}$ and As with the aims to contribute to the definition of the geochemical baseline of southern Tuscany before the human intervention and evaluate the potential dispersion of these harmful elements. The sedimentological, mineralogical and geochemical (major elements) features revealed that the studied profiles are mostly related to the local geological characteristics and the Quaternary geological history of the area. The concentrations and the normalized patterns of trace and rare earth elements highlighted the absence of any anthropogenic activity. This implies that the studied samples are to be regarded as good proxies for evaluating the geochemical baseline of southern Tuscany before the intense mining activity. The enrichment factors (EF) of most trace elements were indeed lower or close to 2, indicating a variability close to the average concentration of the Upper Continental Crust (UCC), while other elements slightly enriched, such as $\mathrm{Pb}$, were in agreement with the natural baseline reported for southern Tuscany. Mercury and As displayed EF values $>40$ when compared to the average contents of UCC, although they decrease down to 4 when compared to the suggested baseline for southern Tuscany. The higher $\mathrm{Hg}$ and As contents detected in this study, inferred to natural sources, evidenced (i) the great natural variability occurring in largely mineralized areas and (ii) the importance of estimating reference environmental parameters in order to avoid misleading interpretations of the detected anomalies. Moreover, the results of leaching test on sediment samples denoted a relatively low mobility of $\mathrm{Hg}$ and As, suggesting that these elements are preferentially mobilized by transport of clastic
\end{abstract}


sediments and such anomalies may be preserved for relatively long times in Quaternary sediments. However, leachable $\mathrm{Hg}(0.6-9.7 \mu \mathrm{g} / \mathrm{L})$ and As (2.1-42.2 $\mu \mathrm{g} / \mathrm{L})$ concentrations are significantly high when compared to those of the Italian limit for groundwater $(1 \mu \mathrm{g} / \mathrm{L}$ for $\mathrm{Hg}$ and $10 \mu \mathrm{g} / \mathrm{L}$ for As $)$. Quaternary sediments from southern Tuscany could then be a potential, though natural, source of $\mathrm{Hg}$ and As to groundwater systems.

Keywords: mercury; arsenic; trace elements; Quaternary sediments; geogenic anomaly; southern Tuscany

\section{Introduction}

Among trace metals, mercury is one of the contaminants of major concern for its high toxicity to human health, cumulative behavior in living organisms and persistence in the environment [1-3]. Likewise, arsenic exerts a toxic effect in a variety of organisms, including humans [4,5]. Because of their harmfulness, many studies have been aimed at assessing mercury [6-9] and arsenic [5,10,11] contents and their mobility in different environmental compartments, especially in highly mineralized areas exploited by mining activities where concentrations up to $1000 \mathrm{mg} / \mathrm{kg}$ were measured in mine waste and alluvial sediments [12-19].

Southern Tuscany (central-western Italy) is an important metallogenic province from which a wide variety of metal resources have been exploited for almost three millennia [20]. Among the ore districts present in this territory, the Mt. Amiata region (Figure 1A) is one of the major mercury districts in the world [21]. The intense exploitation of the cinnabar-rich ore deposits for over a century (1870 to 1974) has produced about $10 \%$ of the global production of elemental $\mathrm{Hg}$ [22-25]. In addition to the Mt. Amiata district, mercury mineralization occurs in different areas down to the coast on the Tyrrhenian sea, outlining an extensive "Hg-zone" (Figure 1A), likely related to the late Tertiary-Quaternary volcanism [26-28]. Pyrite and polymetallic sulfide deposits, containing As-bearing phases such as arsenopyrite, arsenian-pyrite and sulfosalts, are mainly concentrated in the Colline Metallifere ore district (Figure 1A) [29,30]. Here, pyrite was intensively exploited for about a century (1906-1994) with a cumulative production of 80 Mt of pyrite [31,32]. Nevertheless, minor mineral occurrences are widespread in the region, especially along the belt ("pyrite-zone") that extends from the Colline Metallifere district to the Argentario promontory (Figure 1A).

As a consequence of these large geogenic anomalies and the extensive mining activities, mercury [15,33-38] and arsenic [19,39-42] are widely distributed in the environmental matrices of southern Tuscany, creating concern at local, regional and Mediterranean scales. In this context, discriminating natural and anthropogenic contributions in the detected anomalies is not an easy task but it is crucial for evaluating how widespread the environmental pollution is and how the contaminated sites are to be managed. Quaternary sediments deposited in pre-industrial times can be useful to understand and estimate natural transport, dispersion and anomaly contents of trace elements [43-45].

In this study, the presence and distribution of mercury, arsenic and other trace elements were investigated in a succession of sediments and soils/paleosols related to the Late Pleistocene (Marine Isotope Stage, MIS 5) outcropping in a site of southern Tuscany included in the "Hg-zone". The site is located in the Ansedonia area, along the coast of southern Tuscany near the Orbetello Lagoon (Figure 1B) and it was selected since, in the last years, several studies highlighted the presence of anomalous $\mathrm{Hg}$ concentrations in both sediments of the Orbetello Lagoon [46-50] and groundwater from the Ansedonia area [51-54]. The Orbetello Lagoon is a coastal wetland of considerable environmental, economic and social value. Indeed, the lagoon contains a wide variety of vegetation and fauna [55] and hosts numerous tourist (e.g., seaside and naturalistic tourism) and productive activities (e.g., fish farms). The groundwater system constitutes the main water resource of this coastal area exploited for drinking and industrial purposes. Therefore, the aims of this paper are twofold: (i) Contribute to the knowledge 
of geogenic mercury and arsenic anomalies in southern coastal Tuscany and (ii) evaluate the content and mobility of mercury and arsenic in the Quaternary sediments deposited prior of any industrial activity, to be used as a clue on the origin of the anomalies detected in the Ansedonia area and, more in general, the potential origin in other coastal sectors of Tuscany.

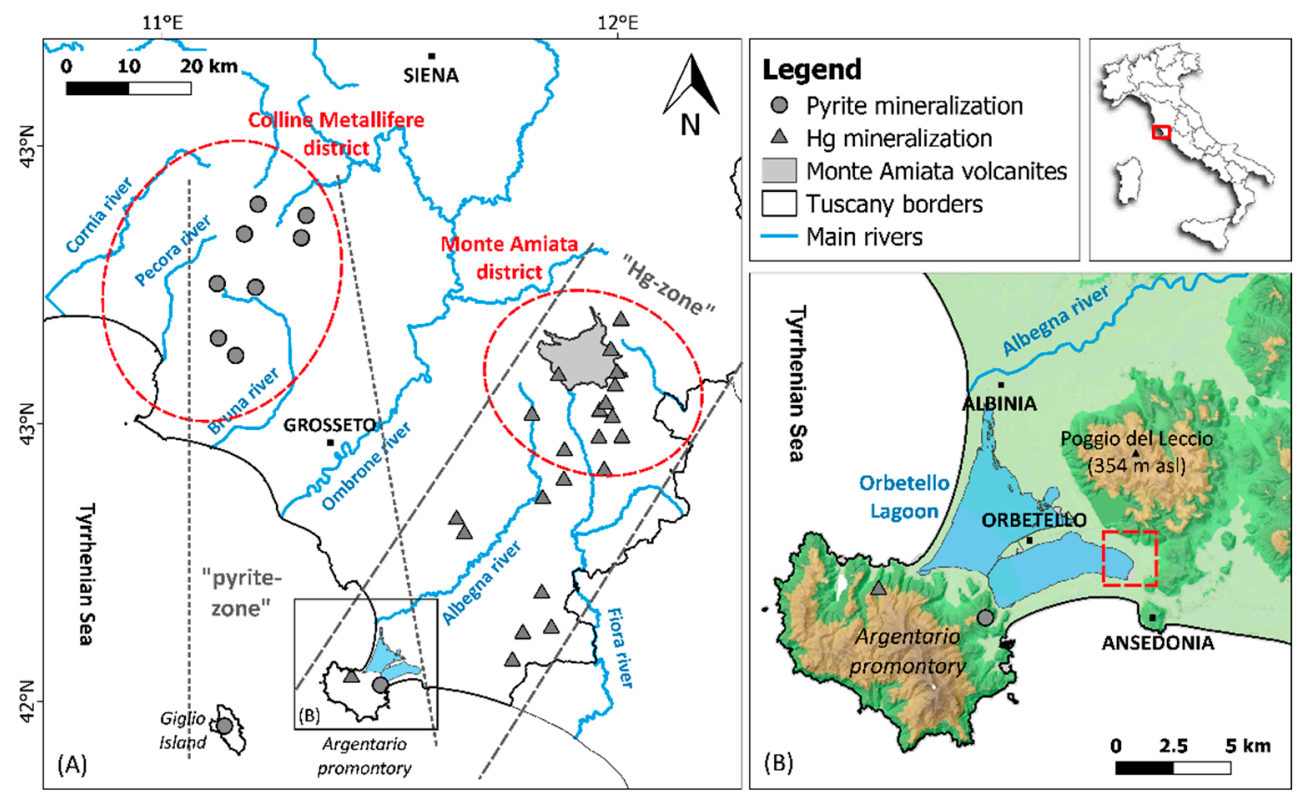

Figure 1. (A) Schematic map showing the location of the main $\mathrm{Hg}$-and pyrite-rich mineralization of southern Tuscany and the outlined "Hg- and pyrite-zone" [26,29,30,36,56]. The red circles point out the Monte Amiata and Colline Metallifere districts, which include the major ore deposits. Figure (B) shows the Orbetello Lagoon and the study area (red square). The background is a classified digital elevation model (DEM $10 \times 10$ ) of Tuscany available on the regional portal "GEOscopio" (https://www502.regione.toscana.it/geoscopio/cartoteca.html).

\section{The Study Area}

\subsection{General Setting and Climate}

The study area (Figure 1B) is part of a coastal plain located in the municipality of Orbetello (Tuscany) between the Orbetello Lagoon, a coastal lagoon with a total area of 2700 ha, the hilly reliefs with a maximum elevation of $354 \mathrm{~m}$ a.s.l. (Poggio del Leccio) and the alluvial plain of the Albegna river to the north. The selected site is a few meters above sea level $(0-10 \mathrm{~m})$ and it is located in a private property belonging to a fish farm. The site, not directly affected by anthropic activities, is close to the Roman road "SS1 Via Aurelia" whilst in the nearby areas several farms are present.

The meteorological data were acquired from the thermo-pluviometric station of Orbetello (ID TOS11000508), located in the central part of the lagoon (WGS84: $42^{\circ} 26^{\prime} 04.01^{\prime \prime} \mathrm{N}, 11^{\circ} 12^{\prime} 09.48^{\prime \prime} \mathrm{E}$ ) at sea level. According to data collected from 1981 to 2010, the average annual rainfall is $600 \pm 195 \mathrm{~mm}$, mostly concentrated from October to December, whereas July is the least rainy month. The average annual temperature is $16.6^{\circ} \mathrm{C}$. The warmest month is August $\left(25.3^{\circ} \mathrm{C}\right)$, while the lowest temperature is recorded in January $\left(9^{\circ} \mathrm{C}\right)$. According to climatic classification of Köppen-Geiger [57], the Orbetello area can be classified as Csa (C: Temperate, s: Dry summer, a: Hot summer).

\subsection{Hydrographic Network}

The study area is located in the drainage basin of the Orbetello Lagoon (Figure 2A) that is limited around the lagoon $\left(\sim 67 \mathrm{~km}^{2}\right)$ and includes small natural and artificial channels. The Orbetello Lagoon drainage basin is adjacent to the Albegna river catchment (Figure 2B), which is one of the major rivers of southern Tuscany, as it flows for $66 \mathrm{~km}$ from Mt. Buceto (1152 m a.s.l.) before entering the Tyrrhenian 
sea. The Albegna river basin includes several mineralized areas that belong to the "Hg-zone" of southern Tuscany (Figure 1A).
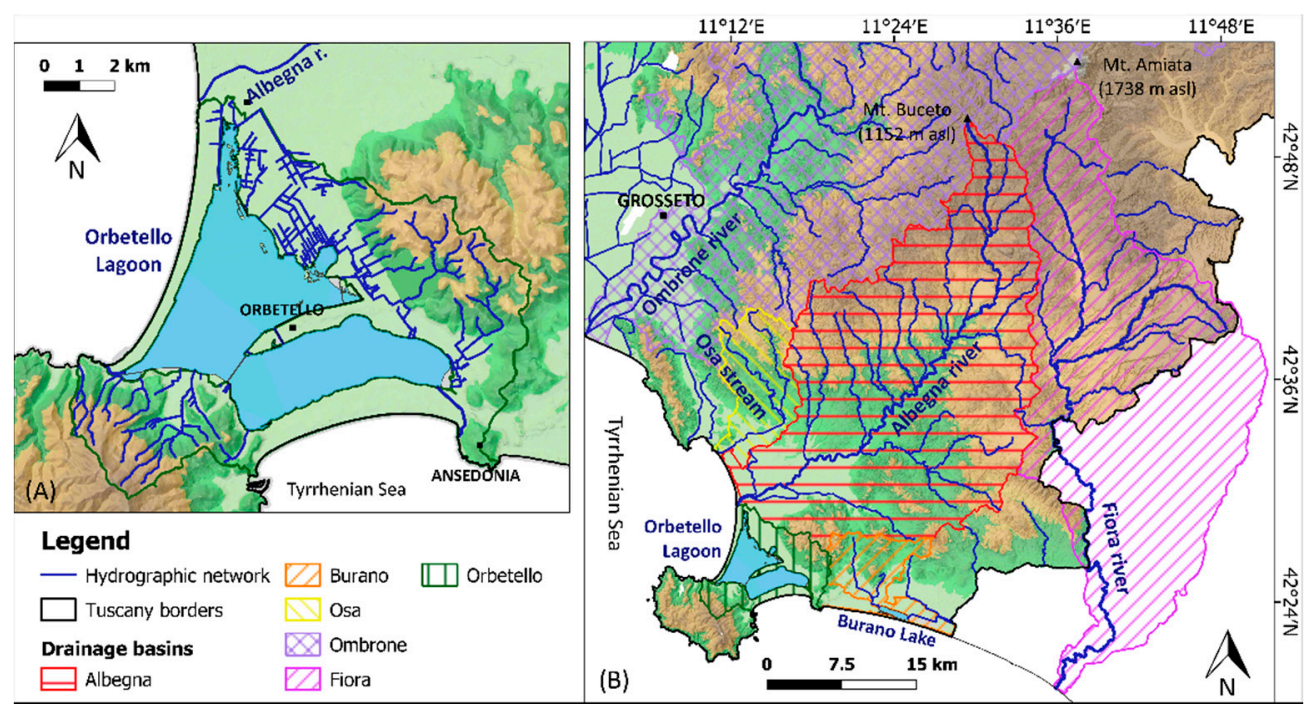

Figure 2. (A) Drainage basin (green line) and hydrographic network of the Orbetello Lagoon. (B) Drainage basins and hydrographic networks of the main rivers and water bodies of southern Tuscany. Sources: "Sistema Informativo Regionale Ambientale della Toscana" (SIRA).

\subsection{Geological and Geomorphological Framework}

From a geological point of view, southern Tuscany is related to the formation of the Apennine chain and consists of several stacked units (from structural bottom to the top: Paleozoic basement, Tuscan Unit and Ligurian Unit) overlaid by Neogene and Quaternary sediments deposited in NW-SE-oriented basins formed during the extensional tectonic phase that followed the Apennine chain formation $[58,59]$.

The Orbetello area is characterized by extensive outcrops of the so-called Calcare Cavernoso (Upper Triassic limestone-dolostone) of the Tuscan Nappe and Quaternary deposits [60] (Figure 3). In this area, the Calcare Cavernoso has a maximum thickness of about 400-600 m and hosts the main local aquifer [53]. At the base of the carbonate formation there is the Verrucano Unit (upper-middle Triassic), that is part of the metamorphic Tuscan complex and it consists of Triassic quartzite and phyllite [61]. The Quaternary sediments overlay these units and record the evolution of the coastal environment, influenced by the Quaternary sea-level fluctuations [62,63]. These deposits vary in thickness from a few to tens of meters and can constitute a multilayered aquifer [53]. Coltorti and Ravani [64] divided the Quaternary sediments of this area in two synthemes or UBSU (Unconformity Bounded Stratigraphic Unit): The Orbetello and the Albegna river synthemes. The "Orbetello synthem" includes alluvial, aeolian and detrital sediments of the Upper Pleistocene and is in turn divided into an upper and lower synthem. The lower one, not outcropping in the investigated area, is represented by coastal sediments deposited during the last sea level high stands (MIS 5e). The uppermost synthem includes the aeolian "Sabbie di Donoratico" sands ("ds" in Figure 3) and the "Ghiaie e detriti di Podere Salciatella e Bellavista" sediments ("ps" in Figure 3), which are debris located around the limestone slopes blended with alluvial deposits of secondary streams. The "Albegna river synthem" includes Upper Pleistocene-Holocene alluvial and beach deposits ("all" and " $\mathrm{db}$ ", respectively, in Figure 3), which are embedded in river and coastal erosion escarpments, delimiting the "Orbetello synthem" deposits. According to the geomorphological reconstruction proposed by Coltorti and Ravani [64], the Pleistocene sediments were cut by the maximum marine Holocene transgression generating an erosion escarpment (Figure 3). Subsequently, the sedimentation of the Albegna river and the local streams generated a rapid advancement of the coast and the development of sandy bars that enclosed the Orbetello Lagoon up to the present morphological configuration. 
The Quaternary sediment profile analyzed in this study is close to the border of the escarpment produced by the Holocene marine transgression and its location is reported in Figure 3 (WGS84/UTM32N: 0687829 E, 4700250 N).

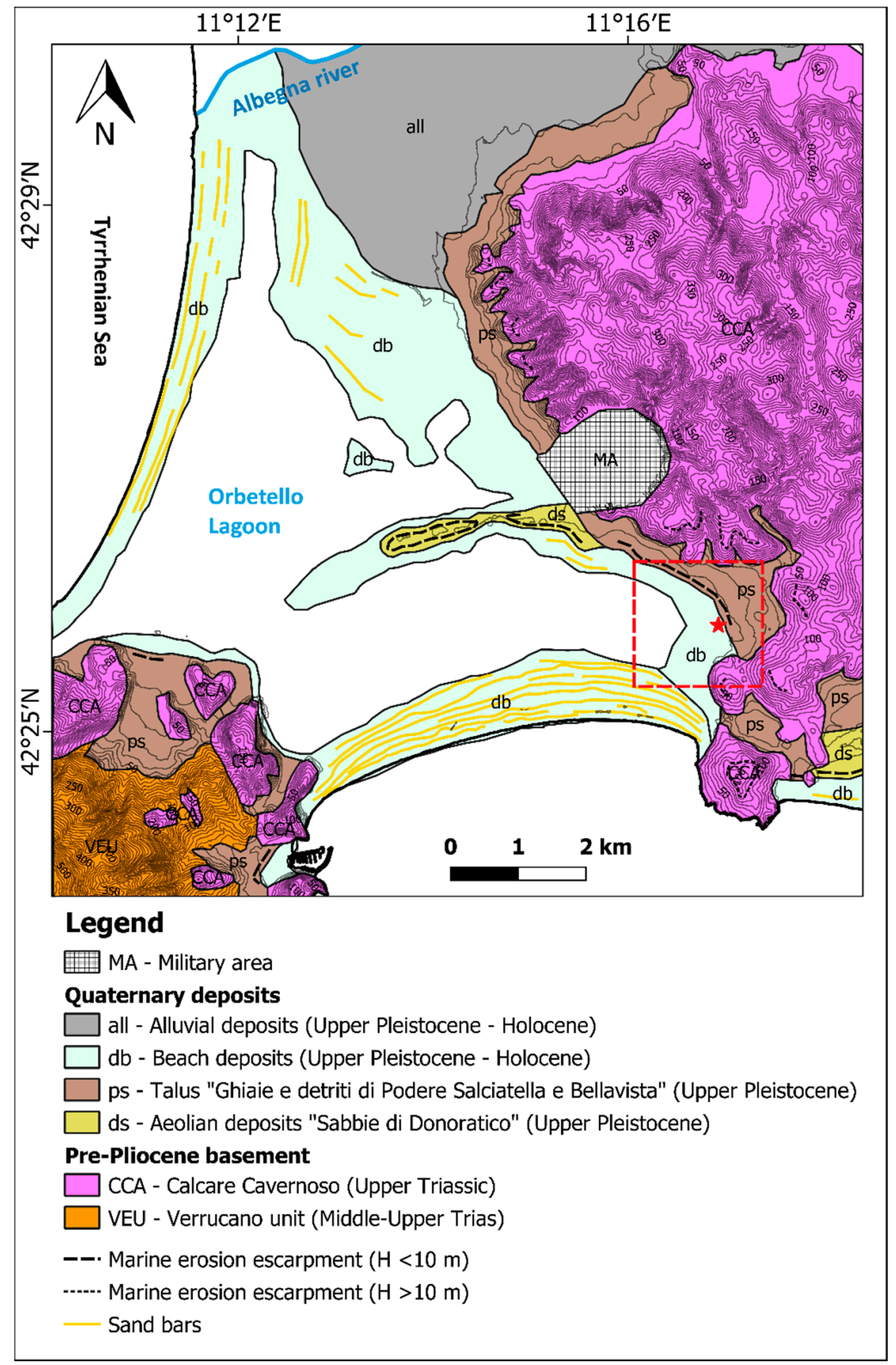

Figure 3. Schematic geological map of the Orbetello area (modified after [64]). The study area and the location of the sediment profile analyzed in this study are indicated, respectively, by the red square and star.

\subsection{Mineralization}

In addition to $\mathrm{Hg}$ and pyrite mineralization, southern Tuscany also hosts many ore deposits, mainly related to the hydrothermal activities of the late Tertiary-Quaternary volcanism $[20,56]$. 
Polymetallic sulfides (largely dominated by pyrite) deposits are also found in the Albegna river catchment that also hosts epithermal Au-Sb deposits [56,65]. In the uppermost part ( 30 m) of the Calcare Cavernoso of the Argentario promontory, which is included in the drainage basin of the Orbetello Lagoon (Figure 2A), mineralized bodies of sulfides (iron, lead and zinc sulfides), limonite and manganese oxide rich-ore deposits were also recognized [49].

\section{Materials and Methods}

\subsection{Field Observations and Sampling}

After a preliminary geological survey to explore the top part of the local Late Pleistocene succession, the selected profile was deepened, and the external layer was removed by an excavator in two sites (vertical Sections A and B), a few meters from each other. Whereupon, lithostratigraphic units and the lithological boundaries were identified, analyzed and described. The stratigraphy of the sections is reported in Figure 4 with the location of the collected samples.

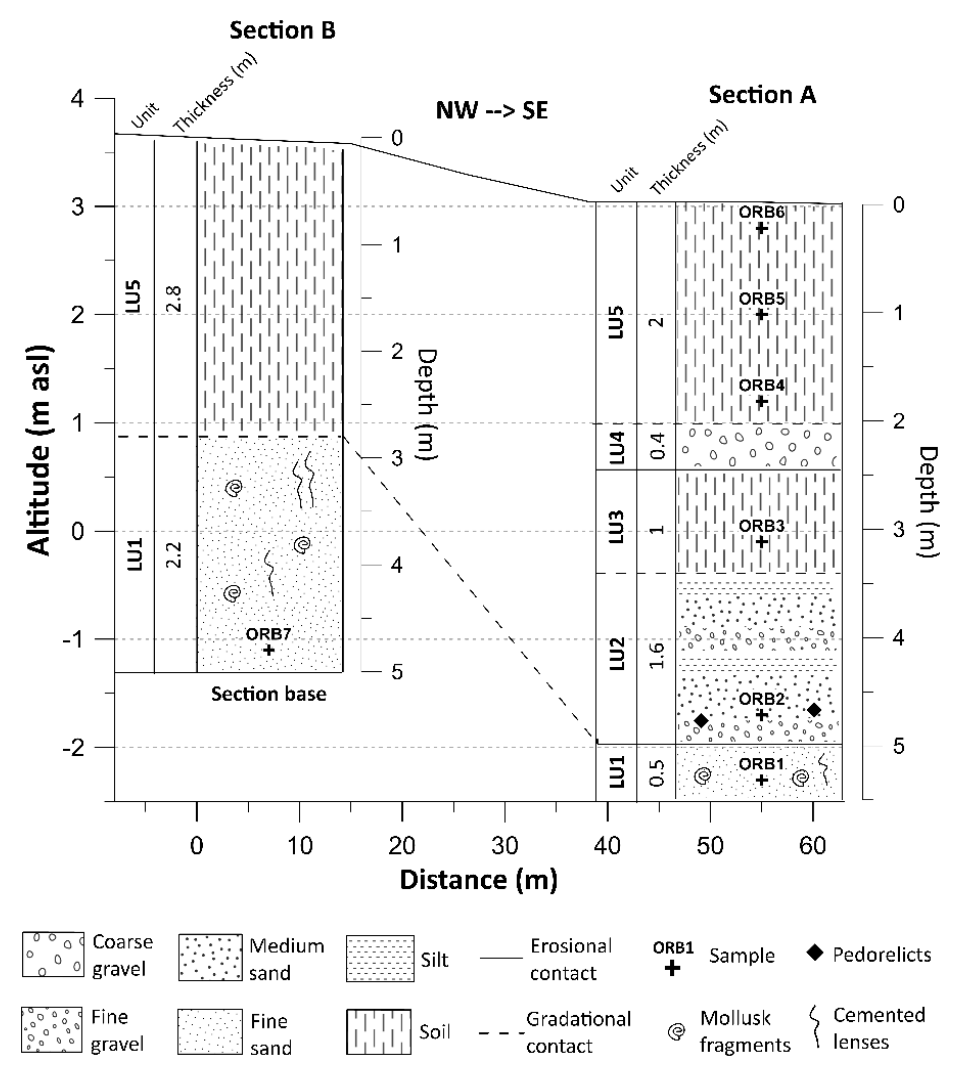

Figure 4. Stratigraphy of the sections with the location of the collected samples. Section A (on the right) and Section B (on the left) are about $50 \mathrm{~m}$ apart. LU1-LU5 are lithostratigraphic units (see text). The graph shows both elevation and depth from the ground level. The width of the sections is not in scale. See Figure 3 for the location of the sections.

The vertical Section A was about $5.5 \mathrm{~m}$ deep from the ground level (3 $\mathrm{m}$ a.s.l.) and 5 lithological units (LU) were distinguished (Figure 4). From the bottom to the top:

- LU1: Loose sands locally cemented; frequent mollusk fragments; wet color 7.5 YR 4/6; $0.5 \mathrm{~m}$ thick (base of the excavation). Sample ORB1 was collected at $5.3 \mathrm{~m}$ from the ground level.

- LU2: Gravel, sand and mud arranged in graded levels; dark thin layers, probably consisting of iron and manganese oxides; rhizoconcrections and pedorelicts; erosional contact at the base; $1.6 \mathrm{~m}$ thick. Sample ORB2 was collected at $4.7 \mathrm{~m}$ from the ground level. 
- LU3: Soil with primary granular structure; gradational lower contact; wet color 5YR 3/4; $1 \mathrm{~m}$ thick. Sample ORB3 was collected at $3.1 \mathrm{~m}$ from the ground level.

- LU4: Loose gravel layer with centimetric pebbles with an erosional contact at the base; $0.4 \mathrm{~m}$ thick. Not sampled.

- LU5: Soil with primary granular structure; gradational lower contact; wet color 5YR 4/4; $2 \mathrm{~m}$ thick. Given the thickness, three samples were collected from this unit: ORB4, ORB5 and ORB6, at $1.8 \mathrm{~m}$, $1 \mathrm{~m}$ and $0.2 \mathrm{~m}$, respectively, from the ground level.

The vertical Section B was about $5 \mathrm{~m}$ deep from the ground level ( $3.7 \mathrm{~m}$ a.s.l.) and presented only two of the previously identified lithological units (Figure 4), from the bottom to the top:

- LU1: Loose sands locally cemented; frequent mollusk fragments; wet color 7.5 YR 4/6 with the basal part slightly darker than LU1 of Section A; $2.2 \mathrm{~m}$ thick (base of the excavation).

- LU5: Soil with primary granular structure; gradational lower contact; wet color 5YR 4/4; $2.8 \mathrm{~m}$ thick.

In this vertical section, the unit LU2, the gravelly level LU4 and, consequently, the unit of soil (LU3), located between them, were absent. From this section, a single sample (ORB7) from LU1 (at $4.8 \mathrm{~m}$ from the ground level) was collected to confirm that it was referred to the same unit found in the Section A.

A total of 4 soil and 3 sediment samples were recovered and placed in a polyethylene jar.

\subsection{Sample Preparation and Laboratory Analyses}

The collected samples were dried at $40{ }^{\circ} \mathrm{C}$ for $48 \mathrm{~h}$ in a forced ventilation oven and the fraction $>2 \mathrm{~mm}$ was discarded before performing grain-size, mineralogical and chemical analyses.

For grain-size classification, the samples were pretreated with hydrogen peroxide solution $2 \%$ $(w / w)$ in $\mathrm{H}_{2} \mathrm{O}$ to enhance the separation of aggregates. Subsequently, the particle size distribution was determined in two different ways for soil and sediment samples: By the Beckman Coulter Multisizer 4 and wet sieving, respectively. The sieve stack consisted of standard ASTM sieves having the following geometrical mean particle diameters: $2 \mathrm{~mm}(-1 \Phi), 1 \mathrm{~mm}(0 \Phi), 0.5 \mathrm{~mm}(1 \Phi), 0.25 \mathrm{~mm}(2 \Phi), 0.125 \mathrm{~mm}$ $(3 \Phi), 0.0625 \mathrm{~mm}(4 \Phi)$. Fractions lower than mud were not determined in the sediment samples. The results were processed with the GRADISTAT Microsoft Excel spreadsheet [66].

The qualitative mineralogical composition was determined by X-ray powder diffraction (XRPD) analysis. The XRPD patterns were obtained using an automatic diffractometer Bruker model D2 PHASER 2nd Generation equipped with a Lynxeye 1D detector and Ni-filtered $\mathrm{Cu} \mathrm{K} \alpha$ radiation $(\lambda=1.5406 \AA)$. All the samples were investigated within the angular range $5-65^{\circ}(2 \Theta)$, with a step size of $0.02^{\circ}(2 \Theta)$ and a counting time of $2 \mathrm{~s}$ per one step. The mineral phases were identified utilizing the Brucker AXS DIFFRAC.EVA software.

Major and minor chemical components $\left(\mathrm{SiO}_{2}, \mathrm{Al}_{2} \mathrm{O}_{3}, \mathrm{Na}_{2} \mathrm{O}, \mathrm{MgO}, \mathrm{P}_{2} \mathrm{O}_{5}, \mathrm{~K} 2 \mathrm{O}, \mathrm{CaO}, \mathrm{TiO}_{2}\right.$, $\mathrm{MnO}, \mathrm{Fe}_{2} \mathrm{O}_{3}$ ) were determined by X-ray fluorescence (XRF) according to the procedure reported in Franzini et al. [67], using an ARL $9400 \mathrm{XP}+$ sequential X-ray spectrometer with the instrumental conditions reported in Lezzerini et al. [68]. The amount of total volatile components was determined as loss on ignition ( $\mathrm{LOI}$ in $105-9500^{\circ} \mathrm{C}$ temperature range).

Trace (Li, Be, Sc, V, Cr, Co, Ni, Ga, Rb, Sr, Y, Zr, Nb, Mo, Cs, Ba, Hf, Ta, W, Pb, Th, U) and rare earth ( $\mathrm{La}, \mathrm{Ce}, \mathrm{Pr}, \mathrm{Nd}, \mathrm{Sm}, \mathrm{Eu}, \mathrm{Gd}, \mathrm{Tb}, \mathrm{Dy}, \mathrm{Ho}, \mathrm{Er}, \mathrm{Tm}, \mathrm{Yb}, \mathrm{Lu}$ ) elements were determined by Inductively Coupled Plasma-Mass Spectrometry (ICP-MS) using a Perkin-Elmer NexION 300x. About 50 mg of each powdered sample was dissolved in a mixture of Suprapur $\mathrm{HF}$ and $\mathrm{HNO}_{3}$ inside perfluoroalkoxy (PFA) vessels on a hot plate at $150{ }^{\circ} \mathrm{C}$. The obtained solutions were properly diluted with ultrapure (Milli-Q) water and mixed online, before reaching the nebulizer, with an internal standard solution containing $20 \mathrm{ng} / \mathrm{mL}$ of $\mathrm{Rh}, \mathrm{Re}$ and Bi to correct for signal fluctuations and matrix effect. The external calibration was used to determine the concentration of each selected element by means of a solution of the BE-N (alkaline basalt) geochemical reference sample [69]. The geochemical reference sample WS-E 
was dissolved and analyzed along with the unknown samples to check the accuracy of the results that is within $6 \%$ for all the elements examined with the exception of Mo (14\%), W (11\%), $\mathrm{Pb}(15 \%)$ and Sc $(18 \%)$.

The concentrations of $\mathrm{Hg}$ and As were measured by Gruppo C.S.A. Ltd. Laboratories in Rimini (Italy), following the procedures reported by the U.S. Environmental Protection Agency (EPA): EPA 3050B 1996 (Acid digestion) + EPA 6020B 2014 (ICP-MS). The chemical composition of the sediment samples (ORB1, ORB2 and ORB7) was carried out on two grain-size fractions $(<2 \mathrm{~mm}$ and $<0.25 \mathrm{~mm}$ ) to verify whether a preferential distribution of $\mathrm{Hg}$ and As on the grain-size was present.

Mobility of $\mathrm{Hg}$ and $\mathrm{As}$ in soil and sediment samples was evaluated by leaching test: $10 \mathrm{~g}$ of each sample were leached with $100 \mathrm{~mL}$ ultrapure (Milli-Q) $\mathrm{CO}_{2}$-saturated water ( $\mathrm{pH} \sim 4.5$ ) for $8 \mathrm{~h}$ and vigorously stirred with a glass rod every $1 \mathrm{~h}$. The leachate, mimicking the effect of meteoric waters [70], was filtered through disposable filters (Sartorius) with cellulose membrane with pores of $0.45 \mu \mathrm{m}$, placed in $50 \mathrm{~mL}$ Falcon tubes and analyzed by Gruppo C.S.A. Ltd. Laboratories in Rimini (Italy). The concentrations of $\mathrm{Hg}$ and As were measured by ICP-MS (Agilent 7500CE, Santa Clara, CA, USA) following the EPA 200.7 and EPA 6020A procedures. Leaching tests were also carried out on the two grain-size fractions selected for $\mathrm{Hg}$ and As analyses ( $<2 \mathrm{~mm}$ and $<0.25 \mathrm{~mm}$ ).

\section{Results}

\subsection{Grain-Size Distribution and Mineralogy}

The grain size distribution and classification for the soil and sediment samples are shown in Figure 5 (the raw data is listed in Table S1 of Supplementary Material). Soil samples from units LU5 (samples ORB6, ORB5, ORB4) and LU3 (sample ORB3), belonging to the vertical Section A, consisted of small particle size classes with a prevalence of silt, which constituted on average $78 \%$ of the total weight. In these samples, the weight classes were represented with an average sorting $(\sigma)$ of about 1.6 $\Phi$ and classified as poorly sorted. According to the soil texture triangle reported by the United State Department of Agriculture (USDA) [71], the soil samples were silt/silt loams. The sediment sample from the unit LU2 (ORB2) consisted of gravel (37\%), sand ( 52\%) and silt ( 9\%) with sandy classes represented rather uniformly (sorting of $2.14 \Phi)$. Therefore, ORB2 was classified as coarse sand, very poorly sorted. The last sample of Section A, ORB1 collected from the unit LU1, was mostly consisting of sand $(\sim 96 \%)$ with a prevalence of the finest classes (sorting of $0.65 \Phi)$. These characteristics led to classifying ORB1 as very fine sand, moderately well sorted. Regarding the vertical Section B, the sample ORB7, collected from the unit LU1, showed features similar to those recorded for ORB1. Accordingly, ORB7 was classified as very fine sand, moderately sorted.

The mineralogical composition of the studied samples is listed in Table 1. The main mineralogical components are reported according to their relative abundance. The main mineralogical phases were quartz, feldspars, phyllosilicates (mostly mica-like minerals) and calcite. Dolomite was also detected in some sediment samples. The relative abundance of the components was similar in the soil (ORB6-3) and the fine sandy (ORB1 and ORB7) samples and different with respect to the coarser sample (ORB2).

Table 1. Mineralogical composition for the studied samples.

\begin{tabular}{ccc}
\hline \multicolumn{2}{c}{ Sample } & \multicolumn{1}{c}{ Mineralogical Composition } \\
\hline \multirow{4}{*}{ Soil } & ORB6 & quartz, feldspars, phyllosilicates, calcite \\
& ORB5 & quartz, feldspars, phyllosilicates, calcite \\
& ORB4 & quartz, feldspars, phyllosilicates, calcite \\
& ORB3 & quartz, feldspars, phyllosilicates, calcite \\
\hline \multirow{3}{*}{ Sediment } & ORB2 & calcite, quartz, feldspars, dolomite, phyllosilicates \\
& ORB1 & quartz, calcite, feldspars, phyllosilicates, dolomite \\
& ORB7 & quartz, calcite, feldspars, phyllosilicates, dolomite \\
\hline
\end{tabular}




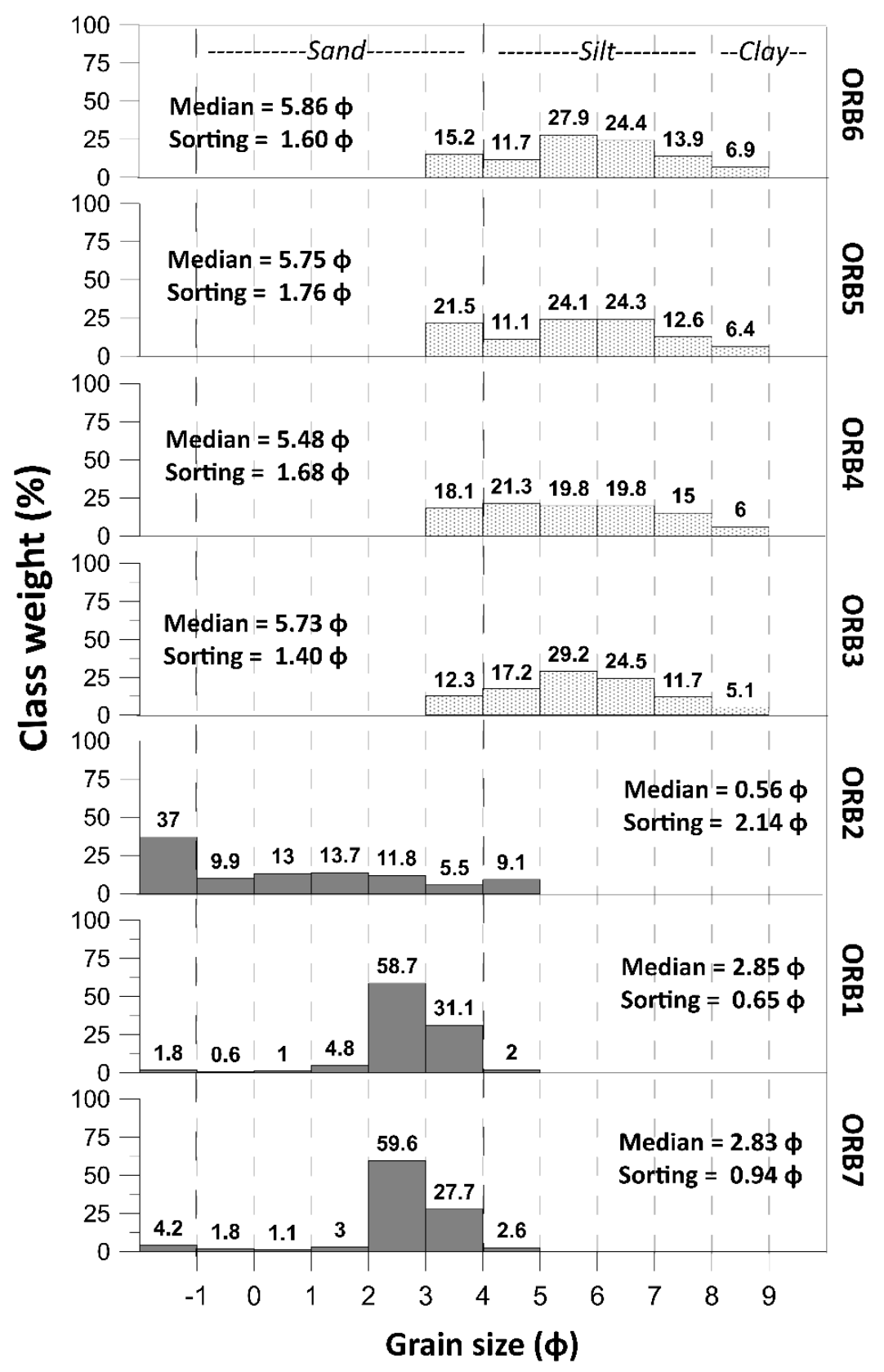

Figure 5. Grain size distribution and classification of the samples. Classification and statistics are obtained through GRADISTAT Microsoft Excel spreadsheet [66].

\subsection{Chemistry}

\subsubsection{Major Elements}

The concentration of the main chemical components is reported as statistics in Table 2 (the complete data are listed in Table S2 of Supplementary Material) and plotted vs. depth in Figure 6. The main chemical composition of the sediment samples (ORB1, ORB2 and ORB7) was consistent with the mineralogical composition, being mainly characterized by $\mathrm{SiO}_{2}$ and $\mathrm{CaO}$, whose sum accounts $>62 \%$ of the total weight, followed by $\mathrm{Al}_{2} \mathrm{O}_{3}(\sim 7.5 \mathrm{wt} \%)$ and $\mathrm{Fe}_{2} \mathrm{O}_{3}(\sim 9 \mathrm{wt} \%)$. Soil samples (ORB6-3) were mainly consisting of $\mathrm{SiO}_{2}(\sim 57 \mathrm{wt} \%), \mathrm{Al}_{2} \mathrm{O}_{3}(\sim 19 \mathrm{wt} \%)$ and $\mathrm{Fe}_{2} \mathrm{O}_{3}(\sim 10 \mathrm{wt} \%)$, while $\mathrm{CaO}$ was lower than $1 \mathrm{wt} \%$. Low contents were recorded for $\mathrm{MgO}$ and $\mathrm{K}_{2} \mathrm{O}$, ranging from about 2 to $5 \mathrm{wt} \%$, whereas other oxides $\left(\mathrm{Na}_{2} \mathrm{O}, \mathrm{P}_{2} \mathrm{O}_{5}, \mathrm{TiO}_{2}\right.$ and $\left.\mathrm{MnO}\right)$ were lower than $1.2 \mathrm{wt} \%$. The average content of $\mathrm{LOI}$ was 
higher for the CaO-rich samples (sediment samples) when compared to the other samples ( 15.5 and $5 \mathrm{wt} \%$, respectively).

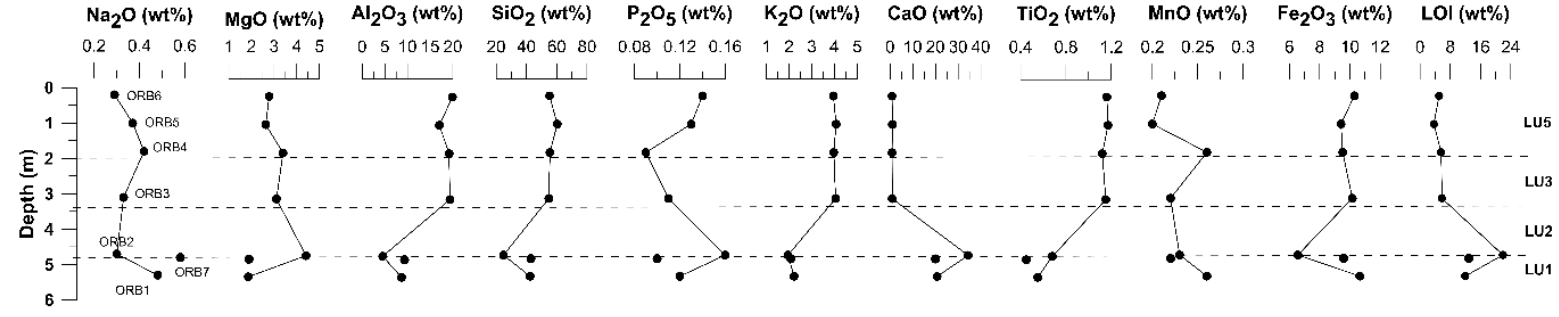

Figure 6. Vertical distribution of major chemical components and loss on ignition (LOI). The vertical lines connect the samples of Section A. Dashed horizontal lines indicate the different lithological units (acronym on the right). The main features of each single unit are summarized in Figure 4 and described in Section 3.1. LU4 (between LU5 and LU3) was not sampled.

The vertical distribution of $\mathrm{Al}_{2} \mathrm{O}_{3}, \mathrm{SiO}_{2}, \mathrm{Fe}_{2} \mathrm{O}_{3}$ and $\mathrm{K}_{2} \mathrm{O}$ (Figure 6) co-varied along the section with the maximum and minimum contents recorded in soil units (LU5 and LU3) and LU2 (coarse sample ORB2), respectively. Similar behavior was shown by $\mathrm{TiO}_{2}$ with the exception of LU1, where the lowest contents were determined. $\mathrm{CaO}$ and LOI had a consistent vertical pattern with minimum values and a rather linear distribution in the upper units and maximum concentrations in LU2. The vertical trends of $\mathrm{MgO}$ and $\mathrm{P}_{2} \mathrm{O}_{5}$ resembled that of $\mathrm{CaO}$, although $\mathrm{MgO}$ presented the minimum value in LU1. The vertical distribution of $\mathrm{Na}_{2} \mathrm{O}$ and $\mathrm{MnO}$ differed from those of other elements, but both had the maximum value in LU1. No significant differences between the ORB1 and ORB7 samples, belonging to LU1 (in both Sections A and B), were observed.

Table 2. Statistics of the main chemical composition for the studied samples (wt \%).

\begin{tabular}{ccccccccccccc}
\hline \multirow{5}{*}{ Soil } & & $\mathbf{N a}_{\mathbf{2}} \mathbf{O}$ & $\mathbf{M g O}$ & $\mathbf{A l}_{\mathbf{2}} \mathbf{O}_{\mathbf{3}}$ & $\mathbf{S i O}_{\mathbf{2}}$ & $\mathbf{P}_{\mathbf{2}} \mathbf{O}_{\mathbf{5}}$ & $\mathbf{K}_{\mathbf{2}} \mathbf{O}$ & $\mathbf{C a O}$ & $\mathrm{TiO}_{2}$ & $\mathbf{M n O}$ & $\mathrm{Fe}_{\mathbf{2}} \mathbf{O}_{\mathbf{3}}$ & $\mathbf{L O I}$ \\
\hline \multirow{5}{*}{ Sediment } & Mean & 0.35 & 2.98 & 18.87 & 56.45 & 0.12 & 4.01 & 0.97 & 1.15 & 0.22 & 9.85 & 5.03 \\
& Min. & 0.29 & 2.63 & 17.03 & 54.75 & 0.09 & 3.95 & 0.93 & 1.12 & 0.20 & 9.41 & 3.65 \\
& Max. & 0.42 & 3.39 & 19.92 & 60.33 & 0.14 & 4.07 & 1.01 & 1.17 & 0.26 & 10.29 & 5.79 \\
\hline & Mean & 0.45 & 2.72 & 7.53 & 36.72 & 0.13 & 2.08 & 25.05 & 0.56 & 0.24 & 8.93 & 15.59 \\
& Min. & 0.30 & 1.86 & 4.54 & 24.85 & 0.10 & 1.95 & 19.97 & 0.45 & 0.22 & 6.56 & 11.96 \\
& Max. & 0.58 & 4.40 & 9.35 & 42.89 & 0.16 & 2.22 & 34.41 & 0.68 & 0.26 & 10.65 & 21.92 \\
\hline
\end{tabular}

\subsubsection{Trace and Rare Earth Elements (REEs)}

The concentration of the trace and rare earth elements are reported as statistics in Table 3 (the complete data are listed in Table S3 of Supplementary Material), where the average concentration of the same elements of the Upper Continental Crust (UCC) [72] is also listed, and plotted vs. depth in Figure 7. The geochemical variation trends normalized with respect to UCC are drawn in Figure 8.

According to the vertical profile of Figure 7, the elements can be divided into four groups, as follows: (1) Li, Mo, Pb, U and, to a lesser extent, $\mathrm{Cr}$ showed the highest contents in ORB4 (LU5) and then, a decrease down to LU1 was observed; (2) V, Ni, Ga, Zr, Nb, Ta, W and Co behaved similar to the elements of Group 1, except for LU1, where a slight increase was observed; (3) Be and Hf had a trend mimicking those of the elements belonging to the Group 2, although a higher abundance was recorded in LU1; (4) Sc, Cs, Th, Rb and Y displayed a rather linear distribution in the upper units (LU5 and LU3), where the highest contents were recorded. Sample ORB2 (LU2) registered the lowest values, while an increase in LU1 was observed. The concentrations of Sr were quite homogeneously distributed along the profile with a slight increase in LU1. The vertical distribution of the REEs was pretty identical and similar to those of Group 4 (Sc, Cs, Th, Rb and Y). 


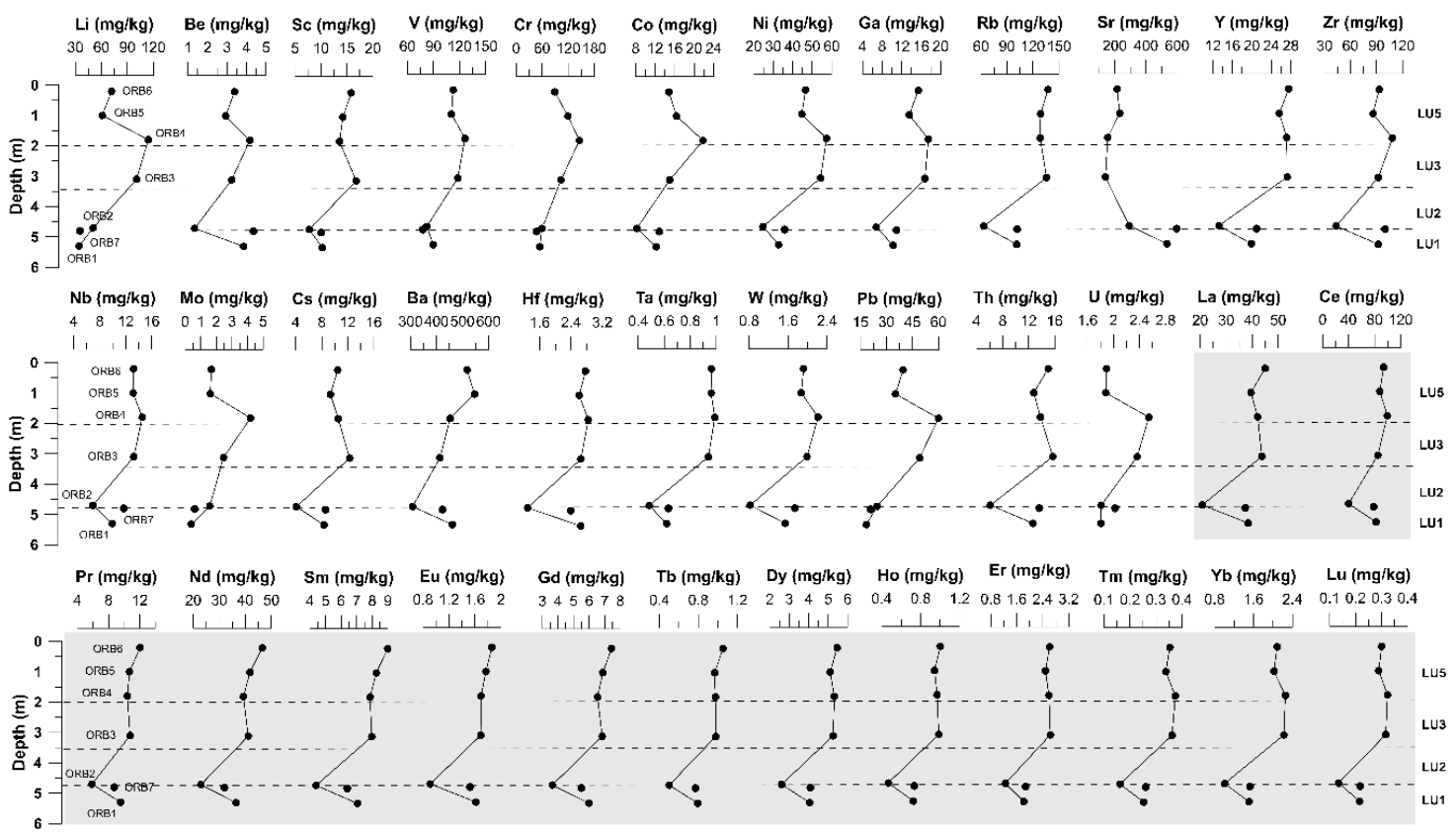

Figure 7. Vertical distribution of trace and rare earth elements (highlighted by gray shadow). The vertical lines connect the samples of Section A. Dashed horizontal lines indicate the different lithological units (abbreviation on the right). The main features of each single unit are summarized in Figure 4 and described in Section 3.1. LU4 (between LU5 and LU3) was not sampled.

Table 3. Statistics of trace and rare earth elements $(\mathrm{mg} / \mathrm{kg})$. UCC refers to the average concentration of elements in the Upper Continental Crust [72].

\begin{tabular}{|c|c|c|c|c|c|c|c|}
\hline & \multicolumn{3}{|c|}{ Soil } & \multicolumn{3}{|c|}{ Sediment } & \multirow[b]{2}{*}{ UCC } \\
\hline & Mean & Min. & Max. & Mean & Min. & Max. & \\
\hline $\mathbf{L i}$ & 87 & 61 & 114 & 40 & 34 & 50 & 20 \\
\hline Be & 3.4 & 2.9 & 4.2 & 3.2 & 1.3 & 4.4 & 3 \\
\hline $\mathrm{Sc}$ & 15 & 14 & 17 & 9.3 & 7.8 & 10 & 13.6 \\
\hline $\mathbf{V}$ & 117 & 111 & 127 & 83 & 78 & 90 & 107 \\
\hline $\mathrm{Cr}$ & 114 & 89 & 146 & 54 & 47 & 60 & 85 \\
\hline Co & 17 & 15 & 22 & 11 & 8.2 & 13 & 17 \\
\hline $\mathrm{Ni}$ & 51 & 45 & 57 & 31 & 25 & 36 & 44 \\
\hline $\mathrm{Ga}$ & 16 & 14 & 17 & 9.3 & 6.8 & 11 & 17 \\
\hline $\mathbf{R b}$ & 133 & 128 & 137 & 89 & 63 & 102 & 112 \\
\hline $\mathrm{Sr}$ & 185 & 140 & 231 & 474 & 292 & 595 & 350 \\
\hline $\mathbf{Y}$ & 27 & 26 & 28 & 18 & 13 & 21 & 22 \\
\hline $\mathrm{Zr}$ & 95 & 86 & 108 & 78 & 43 & 100 & 190 \\
\hline $\mathrm{Nb}$ & 14 & 13 & 15 & 9.6 & 6.9 & 12 & 12 \\
\hline Mo & 2.5 & 1.6 & 4.2 & 0.87 & 0.4 & 1.6 & 1.5 \\
\hline Cs & 11 & 9.3 & 12 & 7 & 4.1 & 8.6 & 4.6 \\
\hline $\mathbf{B a}$ & 483 & 413 & 547 & 398 & 308 & 462 & 550 \\
\hline Hf & 2.7 & 2.6 & 2.8 & 2.1 & 1.3 & 2.7 & 5.8 \\
\hline Ta & 0.96 & 0.94 & 0.99 & 0.58 & 0.48 & 0.63 & 1 \\
\hline $\mathbf{W}$ & 2 & 1.9 & 2.2 & 1.3 & 0.82 & 1.7 & 2 \\
\hline $\mathrm{Pb}$ & 46 & 35 & 60 & 21 & 18 & 25 & 17 \\
\hline Th & 15 & 13 & 16 & 11 & 6.1 & 14 & 10.7 \\
\hline $\mathbf{U}$ & 2.2 & 1.9 & 2.5 & 1.9 & 1.8 & 2 & 2.8 \\
\hline $\mathrm{La}$ & 43 & 40 & 45 & 32 & 21 & 38 & 30 \\
\hline $\mathrm{Ce}$ & 92 & 85 & 99 & 67 & 40 & 82 & 64 \\
\hline $\operatorname{Pr}$ & 11 & 10 & 12 & 8.1 & 5.9 & 9.6 & 7.1 \\
\hline Nd & 42 & 39 & 46 & 30 & 23 & 36 & 26 \\
\hline
\end{tabular}


Table 3. Cont.

\begin{tabular}{cccccccc}
\hline & \multicolumn{3}{c}{ Soil } & \multicolumn{5}{c}{ Sediment } \\
\cline { 2 - 6 } & Mean & Min. & Max. & Mean & Min. & Max. & UCC \\
\hline Sm & 8.3 & 7.9 & 9 & 6 & 4.4 & 7.1 & 4.5 \\
Eu & 1.8 & 1.7 & 1.9 & 1.3 & 0.91 & 1.6 & 0.88 \\
Gd & 6.9 & 6.5 & 7.4 & 5 & 3.6 & 6 & 3.8 \\
Tb & 1 & 0.97 & 1.1 & 0.69 & 0.5 & 0.79 & 0.64 \\
Dy & 5.3 & 5.1 & 5.5 & 3.6 & 2.6 & 4.1 & 3.5 \\
Ho & 0.98 & 0.94 & 1 & 0.65 & 0.47 & 0.74 & 0.8 \\
Er & 2.6 & 2.5 & 2.6 & 1.7 & 1.3 & 1.9 & 2.3 \\
Tm & 0.36 & 0.34 & 0.37 & 0.22 & 0.16 & 0.26 & 0.33 \\
Yb & 2.2 & 2 & 2.3 & 1.3 & 1 & 1.5 & 2.2 \\
Lu & 0.31 & 0.29 & 0.32 & 0.19 & 0.13 & 0.22 & 0.32 \\
\hline
\end{tabular}
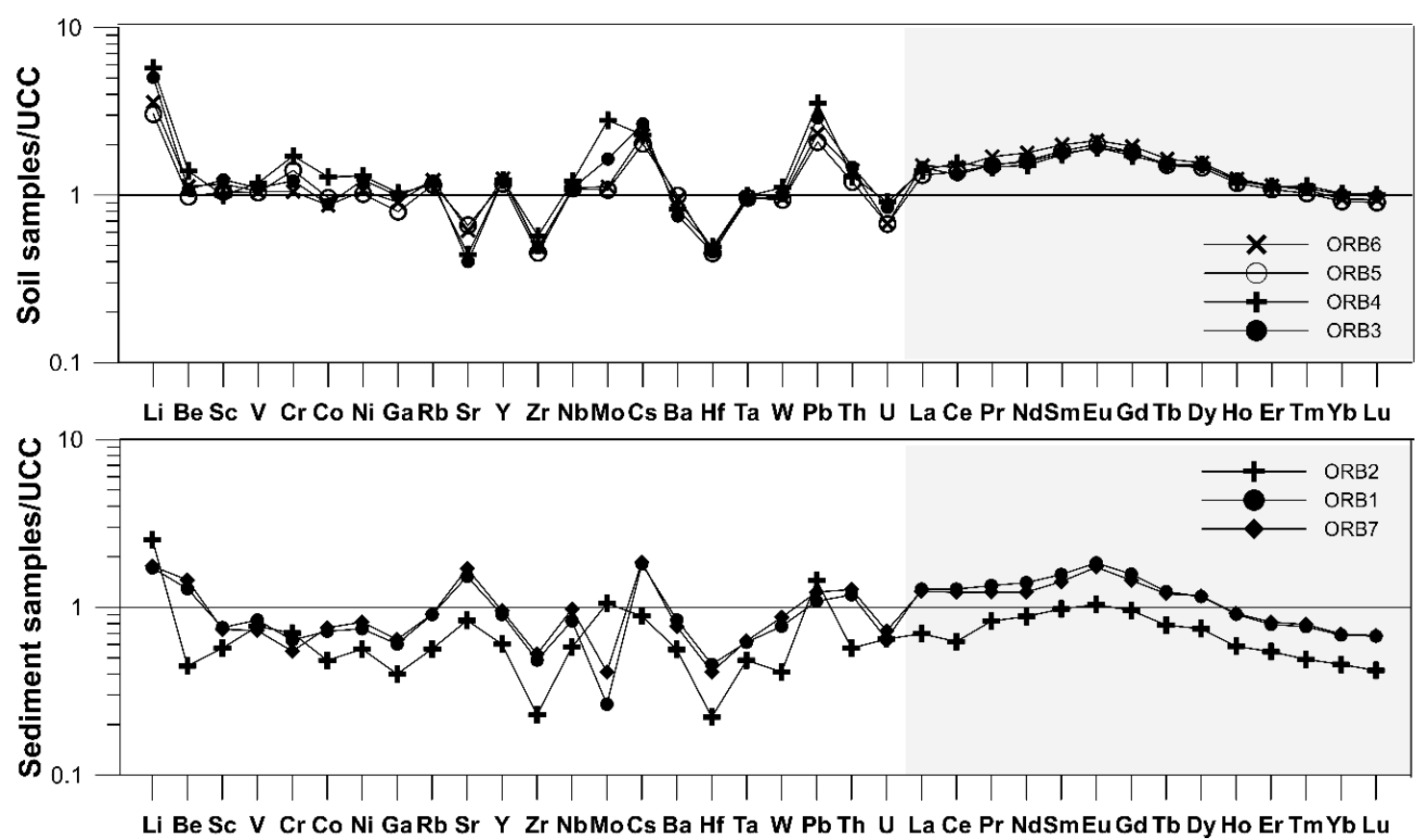

Figure 8. Trace element and REE (highlighted by gray shadow) abundance patterns normalized to UCC (McLennan, 2001) for soil and sediment samples. The $Y$-axis is logarithmic (Log base 10).

\subsubsection{Mercury and Arsenic Concentrations and Mobility}

Total concentrations of $\mathrm{Hg}$ and As are reported in Table 4 and plotted vs. depth in Figure 9. In the fraction $<2 \mathrm{~mm}$, mercury contents were from 0.2 (ORB1) up to 2.7 (ORB3) $\mathrm{mg} / \mathrm{kg}$. Soil samples showed concentrations of $\mathrm{Hg}$ increasing with depth in soil units (LU5 and LU3) and then, an abrupt decrease to the bottom of the profile was observed. Arsenic showed concentrations between 15.8 (ORB2) and 44.9 (ORB7) $\mathrm{mg} / \mathrm{kg}$. For As, the highest values were found in sandy-rich samples (ORB1 and ORB7). No $\mathrm{Hg}$ and As enrichments were evidenced in the fraction $<0.25 \mathrm{~mm}$, except for the sample ORB2, the finer fraction being $\sim 2.5$ times more enriched than the fraction $<2 \mathrm{~mm}$.

The results of the leaching tests are shown in Table 5. In the fraction $<2 \mathrm{~mm}, \mathrm{Hg}$ showed concentrations between 0.6 (ORB5) and 9.7 (ORB1) $\mu \mathrm{g} / \mathrm{L}$, while As varied from 2.1 (ORB6) up to 42.2 (ORB7) $\mu \mathrm{g} / \mathrm{L}$. In the fraction $<0.25 \mathrm{~mm}$, the leachable contents of $\mathrm{Hg}$ and As were similar, except for ORB1, the Hg content being lower. The values of column "\% leached" reported in Table 5 were calculated by comparing the amount of $\mathrm{Hg}$ and As leached with their total concentrations measured in the bulk (Table 4). Setting aside ORB1, where $~ 50 \%$ of $\mathrm{Hg}$ from the fraction $<2 \mathrm{~mm}$ was leached, in the other samples the leached percentage was $<3 \%$. 
Table 4. Concentrations in $\mathrm{mg} / \mathrm{kg}$ of $\mathrm{Hg}$ and As analyzed on two grain-size fractions.

\begin{tabular}{|c|c|c|c|c|c|}
\hline \multirow[b]{2}{*}{ Sampl } & & \multicolumn{2}{|c|}{$\mathrm{Hg}(\mathrm{mg} / \mathrm{kg})$} & \multicolumn{2}{|c|}{ As (mg/kg) } \\
\hline & & Grain-Size $<2 \mathrm{~mm}$ & Grain-Size $<0.25 \mathrm{~mm}$ & Grain-Size $<2 \mathrm{~mm}$ & Grain-Size $<0.25 \mathrm{~mm}$ \\
\hline \multirow{4}{*}{ Soil } & ORB6 & 1.1 & - & 29.6 & - \\
\hline & ORB5 & 1.5 & - & 25.4 & - \\
\hline & ORB4 & 1.5 & - & 30.2 & - \\
\hline & ORB3 & 2.7 & - & 27.8 & - \\
\hline \multirow{3}{*}{ Sediment } & ORB2 & 1.0 & 2.5 & 15.8 & 20.5 \\
\hline & ORB1 & 0.2 & 0.2 & 36.2 & 36.7 \\
\hline & ORB7 & 0.5 & 0.3 & 44.9 & 45.9 \\
\hline
\end{tabular}

\section{$\mathrm{Hg}(\mathrm{mg} / \mathrm{kg}) \quad$ As $(\mathrm{mg} / \mathrm{kg})$}

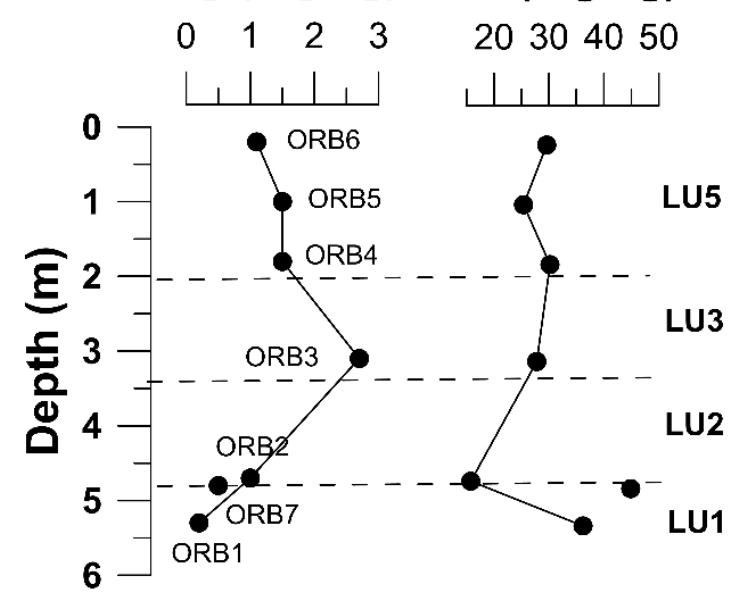

Figure 9. Vertical distribution of $\mathrm{Hg}$ and $\mathrm{As}$ in the fraction $<2 \mathrm{~mm}$. The vertical lines connect the samples of Section A. Dashed horizontal lines indicatesthe different lithological units (abbreviation on the right). The main features of each single unit are summarized in Figure 4 and described in Section 3.1. LU4 (between LU5 and LU3) was not sampled.

Table 5. Concentrations $(\mu \mathrm{g} / \mathrm{L})$ of $\mathrm{Hg}$ and As determined in the leached samples. "\% leached" refers to the amount of leached element respect to the total concentration measured in the bulk and reported in Table 4.

\begin{tabular}{|c|c|c|c|c|c|c|c|c|c|}
\hline \multirow{3}{*}{ Sample } & & \multicolumn{4}{|c|}{$\mathrm{Hg}$} & \multicolumn{4}{|c|}{ As } \\
\hline & & \multicolumn{2}{|c|}{ Grain-Size $<2 \mathrm{~mm}$} & \multicolumn{2}{|c|}{ Grain-Size $<0.25 \mathrm{~mm}$} & \multicolumn{2}{|c|}{ Grain-Size $<2 \mathrm{~mm}$} & \multicolumn{2}{|c|}{ Grain-Size $<0.25 \mathrm{~mm}$} \\
\hline & & $\mu \mathrm{g} / \mathrm{L}$ & \% leached & $\mu \mathrm{g} / \mathrm{L}$ & $\%$ leached & $\mu \mathrm{g} / \mathrm{L}$ & \% leached & $\mu \mathrm{g} / \mathrm{L}$ & \% leached \\
\hline \multirow{4}{*}{ Soil } & ORB6 & 1.2 & 1.1 & - & - & 2.1 & 0.1 & - & - \\
\hline & ORB5 & 0.6 & 0.4 & - & - & 2.4 & 0.1 & - & - \\
\hline & ORB4 & 3.2 & 2.1 & - & - & 2.4 & 0.1 & - & - \\
\hline & ORB3 & 0.9 & 0.3 & - & - & 2.2 & 0.1 & - & - \\
\hline \multirow{3}{*}{ Sediment } & ORB2 & 1.1 & 1.1 & 1.9 & 0.8 & 6.7 & 0.4 & 9.2 & 0.4 \\
\hline & ORB1 & 9.7 & 48.5 & 0.5 & 2.5 & 33.2 & 0.9 & 34.3 & 0.9 \\
\hline & ORB7 & 1.4 & 2.8 & 0.6 & 2.0 & 36.7 & 0.8 & 42.2 & 0.9 \\
\hline
\end{tabular}

\section{Discussion}

\subsection{Major Components Geochemistry and Interpretation of the Sections}

Source rock type, weathering processes and sorting are the main factors that control the geochemistry of clastic sediments and soils [73]. The study area is part of the coastal plain developed by the Albegna river and local streams in the Orbetello area. Therefore, sediment chemistry is affected by geological characteristics of the river catchment and the drainage basin of the Orbetello Lagoon. As previously described, carbonate lithologies (Calcare Cavernoso Fm.) prevail in the Orbetello Lagoon 
basin whereas the Albegna catchment is characterized by a relatively large variety of sedimentary rocks: Turbidites, sandstones, carbonates and evaporites [63,74]. To understand the distribution of major elements in soil and sediments samples, variation diagrams using $\mathrm{Al}_{2} \mathrm{O}_{3}$ (in the $X$-axis) as immobile element [75] are reported in Figure 10. For the sake of clarity, the estimated average of the UCC [72] and Post Archean Australian Shale (PAAS) [76], along with the average contents of major elements of the Calcare Cavernoso (CCA) from the Ansedonia area [77] are also included in Figure 10. The chemical composition of sediments (black symbols) is mainly controlled by the presence of carbonates, whereas that of soils (open symbols) is mainly related to grain size and weathering processes. The main components of sediment samples, i.e., $\mathrm{SiO}_{2}$ and $\mathrm{CaO}$, are indeed directly and inversely correlated with $\mathrm{Al}_{2} \mathrm{O}_{3}$, respectively, and approach that of CCA (Figure 10C,F, respectively). The opposite distribution of $\mathrm{SiO}_{2}$ and $\mathrm{CaO}$ in the vertical profiles of Figure 6 indicates that calcite was primary rather than secondary because the presence of secondary carbonates is expected to produce scattered $\mathrm{SiO}_{2} \mathrm{wt} \%$ vs. $\mathrm{CaO} w \mathrm{wt} \%$ plots [78]. The dilution effect induced by carbonate component is also highlighted, though at a minor extent, by $\mathrm{Na}_{2} \mathrm{O}$ (Figure 10A), $\mathrm{MgO}$ (Figure 10B) and $\mathrm{K}_{2} \mathrm{O}$ (Figure 10E) vs. $\mathrm{Al}_{2} \mathrm{O}_{3}$. This implies that, as expected, the Calcare Cavernoso Fm. is a remarkable source rock for the sediments from the study area. Furthermore, the chemical composition of ORB1 and ORB7 (sandy samples from LU1) is closer to those of UCC and PAAS than that of ORB2 (LU2). This behavior suggests that the LU1 sediments are likely the result of longer transport and greater homogenization of eroded lithologies whereas those of LU2 are mainly related to a proximal source. Field observations are apparently supporting this statement since the absence of LU2 in Section B indicates very local processes involved in its deposition in Section A likely related to a preferential water flow path of ancient streams and/or runoff-water of the Orbetello Lagoon basin. The negative relationship between $\mathrm{SiO}_{2}$ and $\mathrm{Al}_{2} \mathrm{O}_{3}$ (Figure 10C) in the soils indicates the role of physical sorting that affect their composition, $\mathrm{Al}_{2} \mathrm{O}_{3}$ increasing in fine-rich grain size samples whereas $\mathrm{SiO}_{2}$ is enriched in coarse grain-size samples. Leaching processes are instead inferable from the depletion of $\mathrm{Na}_{2} \mathrm{O}$ (Figure 10A) and $\mathrm{CaO}$ (Figure 10F) with respect to UCC and PAAS, Na-bearing and carbonate minerals being more easily alterable than K-minerals [79]. Co-variation between $\mathrm{K}_{2} \mathrm{O}$ and $\mathrm{Al}_{2} \mathrm{O}_{3}$ (Figure 10E) reflects how $\mathrm{K}$-bearing minerals are able to influence the $\mathrm{Al}$ contents (e.g., phyllosilicates are mostly micas, as shown by XRD analyses). The behavior of $\mathrm{TiO}_{2}$ (Figure 10G) is similar to that of $\mathrm{Al}_{2} \mathrm{O}_{3}$, being a rather immobile element that tends to be enriched in refractory minerals, whereas the slight enrichment in $\mathrm{Fe}_{2} \mathrm{O}_{3}$ (Figure 10I) for all the samples is likely related to mobilization of $\mathrm{Fe}^{2+}$ by weathering of primary minerals and reprecipitation as $\mathrm{Fe}^{\mathrm{III}}$ oxides [80]. The $\mathrm{MnO}$ and $\mathrm{P}_{2} \mathrm{O}_{5}$ contents are low and their behavior vs. $\mathrm{Al}_{2} \mathrm{O}_{3}$ (Figure $10 \mathrm{H}, \mathrm{D}$, respectively) is rather scattered, suggesting that there is not a dominant component that governs their distribution.

To estimate the degree of chemical weathering undergone by the rocks (and soils) of the source areas, the most popular chemical index of alteration (CIA) was evaluated. This index represents a practical way to measure the chemical alteration assuming that when the intensity of chemical weathering processes increases, the content of the most mobile ions, such as calcium, sodium and potassium decreases. This produces an increment in the CIA values [81]. The CIA, expressed in molar proportions of oxides, is calculated by the following formula:

$$
\mathrm{CIA}=\frac{\mathrm{Al}_{2} \mathrm{O}_{3}}{\left(\mathrm{Al}_{2} \mathrm{O}_{3}+\mathrm{CaO}^{*}+\mathrm{Na}_{2} \mathrm{O}+\mathrm{K}_{2} \mathrm{O}\right)} \times 100
$$

where $\mathrm{CaO}^{*}$ is referred to the silicate fraction. Thus, the measured $\mathrm{CaO}$ content is corrected according to the presence of $\mathrm{Ca}$ in carbonates and phosphates and computed from measured $\mathrm{CO}_{2}$ and $\mathrm{P}_{2} \mathrm{O}_{5}$ contents. When these data are not available (as in the case of $\mathrm{CO}_{2}$ ), McLennan [81] suggested to compare the number of moles of $\mathrm{CaO}$ with those $\mathrm{Na}_{2} \mathrm{O}$ : If the number of moles is greater than $\mathrm{Na}_{2} \mathrm{O}$, $\mathrm{CaO}^{*}$ is assumed to be equivalent to $\mathrm{Na}_{2} \mathrm{O}$, otherwise the $\mathrm{CaO}$ value can be adopted. In this study, this procedure was followed. The results of calculations are listed in Table 6. 

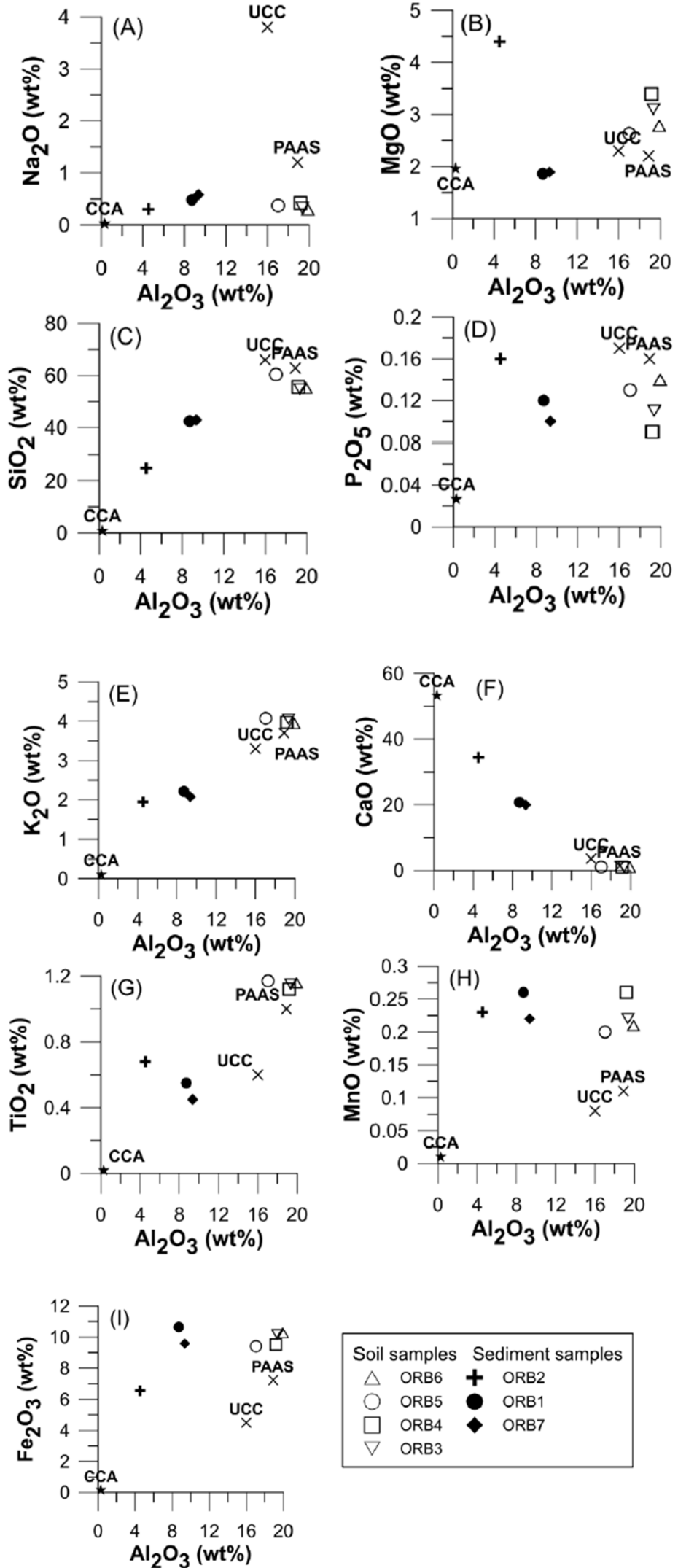

Soil samples Sediment samples

$\triangle$ ORB6 + ORB2

$\bigcirc$ ORB5

$\square \quad$ ORB4

ORB3

ORB1
ORB7

Figure 10. Variation diagrams of major elements of sediment (black symbols) and soil samples (open symbols) plotted against $\mathrm{Al}_{2} \mathrm{O}_{3}$ : (A) $\mathrm{Na}_{2} \mathrm{O}$ vs. $\mathrm{Al}_{2} \mathrm{O}_{3}$; (B) $\mathrm{MgO}$ vs. $\mathrm{Al}_{2} \mathrm{O}_{3}$; (C) $\mathrm{SiO}_{2}$ vs. $\mathrm{Al}_{2} \mathrm{O}_{3}$; (D) $\mathrm{P}_{2} \mathrm{O}_{5}$ vs. $\mathrm{Al}_{2} \mathrm{O}_{3} ;\left(\right.$ E) $\mathrm{K}_{2} \mathrm{O}$ vs. $\mathrm{Al}_{2} \mathrm{O}_{3} ;$ (F) $\mathrm{CaO}$ vs. $\mathrm{Al}_{2} \mathrm{O}_{3} ;(\mathbf{G}) \mathrm{TiO}_{2}$ vs. $\mathrm{Al}_{2} \mathrm{O}_{3} ;$ (H) $\mathrm{MnO}$ vs $\mathrm{Al}_{2} \mathrm{O}_{3} ;(\mathbf{I}) \mathrm{Fe}_{2} \mathrm{O}_{3}$ vs $\mathrm{Al}_{2} \mathrm{O}_{3}$. Composition of major elements of UCC, Post Archean Australian Shale (PAAS) and the Calcare Cavernoso (CCA) of the Ansedonia area are shown for comparison. 
Table 6. Chemical Index of Alteration (CIA) values.

\begin{tabular}{cccccccc}
\hline & \multicolumn{4}{c}{ Soil } & \multicolumn{3}{c}{ Sediment } \\
\cline { 2 - 8 } & ORB6 & ORB5 & ORB4 & ORB3 & ORB2 & ORB1 & ORB7 \\
\hline CIA & 79 & 75 & 77 & 78 & 59 & 69 & 69 \\
\hline
\end{tabular}

All the samples have CIA values higher than that of UCC (50), which indicates a rather efficient weathering process. As expected, soil samples show the highest values (75-79). It is to note that ORB2 has the lowest CIA value, which supports its local origin from relatively fresh eroded material.

Overall, field observations and major element distribution along the vertical Section A can be interpreted from the bottom to the top, as follows: LU1 (5-5.5 m depth), a fine sand with frequent marine fossils, represents a coastal beach mainly fed by sediments from the Albegna river (longer transport) and longshore distribution. In agreement with the study of Coltorti and Ravani [64], LU1 might correspond to the lower part of the "Orbetello synthem", which is constituted by coastal sediments deposited during the last sea level high stands (MIS 5e). LU2 (3.4-5 m depth), graded levels of gravel, sand and silt, can be attributed to local transport and therefore, mainly affected by the lithological features of the Orbetello Lagoon basin. The erosional contact at the base of this unit and the presence of reworked rhizoconcrections and pedorelicts suggest that above LU1 there was a soil eroded by LU2. In this case, the depositional interval between these units might be quite long to allow LU1 to undergo pedogenetic processes. LU3 (2.4-3.4 m depth), a silty soil with gradational lower contact, can be the result of pedogenetic processes on LU2. These processes were probably interrupted by a fluvial gravel depositional event (UL4: $40 \mathrm{~cm}$ thick), which was then followed by the formation of LU5, the last silty soil unit that reaches the ground level. As far as the vertical Section B is concerned, the presence of soil above LU1 and the absence of the other units indicate that no event of transport of local stream and/or run-off water occurred, thus favoring the profile to be accumulated (i.e., weathering $>>$ than sedimentary events). Consequently, the soil has developed an apparently thick continuous profile. Moreover, the reddish brown color suggests pedogenetic processes such as rubefaction, typical of old and well-drained soils in the Mediterranean area [82]. From a pedogenetic point of view, soils from units LU5 and LU2 can hence represent truncated Bt horizons.

\subsection{Trace Elements Geochemistry}

Trace and REE patterns normalized to UCC (Figure 8) are characterized by higher values in soil samples when compared to those of the sediments, especially the coarsest and $\mathrm{CaO}$-richest sample ORB2. According to major elements geochemistry, these trends suggest that trace and REEs are mainly governed by grain size sorting (e.g., the finer fractions are enriched in trace and REE elements) and dilution effect (e.g., sediment samples are carbonate-rich with low contents of trace and REE elements). Therefore, to avoid the grain size effect and better highlight the behavior of trace and REE elements, the enrichment factor (EF) index was calculated [83]. The metal concentrations were normalized to aluminum as a grain-size proxy, this element being a major constituent of clay minerals. The UCC concentrations were used as background values. The EF is expressed, as follows:

$$
\mathrm{EF}=\frac{(\mathrm{Metal} / \mathrm{Al})_{\text {sample }}}{(\text { Metal } / \mathrm{Al})_{\text {background }}}
$$

where $(\mathrm{Metal} / \mathrm{Al})_{\text {sample }}$ and $(\mathrm{Metal} / \mathrm{Al})_{\text {background }}$ are the observed and reference values of the metal $(\mathrm{mg} / \mathrm{kg})$ to $\mathrm{Al}(\%)$ ratio, respectively. The results of the calculations are reported as box and whiskers plot in Figure 11. Mercury and As are also included in the graph although they will be discussed in the next section.

Generally speaking, the overall pattern of EFs (Figure 11) is similar to those of the spider diagrams (Figure 8). Most trace elements (Be, Sc, V, Cr, Co, Ni, Ga, Rb, Y, Zr, Nb, Ba, Hf, W, Th and U) show 
EF values lower or close to 2, indicating a minimal enrichment and a variability close to the average concentration of UCC. Lithium, Mo, Cs and Pb are moderately enriched (EF < 5). Nevertheless, $\mathrm{Pb}$ concentrations in the studied samples are in agreement with the anomalies reported for southern Tuscany by Protano et al. [84]. Pb anomalies are related to natural variabilities since they are due to the presence of polymetallic sulfide-rich ore deposits and hydrothermal activity that characterize southern Tuscany. Since Li and Mo show the same vertical trend of $\mathrm{Pb}$ (Figure 7), it is reasonable to assume that their distribution is probably related to the same source, i.e., the ore deposits from southern Tuscany [56]. The EF of Cs (a Large Ion Lithophile Element, LILE) can be associated with its vertical distribution reported in Figure 8, resembling those of other LILE, e.g., $\mathrm{Rb}$ and Th, which, at their turn, are comparable with the vertical distributions of $\mathrm{Al}_{2} \mathrm{O}_{3}$ and $\mathrm{K}_{2} \mathrm{O}$ (Figure 7). This may imply that they can be allocated in phyllosilicate minerals. In particular, chemical weathering favors the release of $\mathrm{Cs}$, which is then promptly adsorbed by clay minerals in soils where an average content of $15 \mathrm{mg} / \mathrm{kg}$ was determined [85]. Strontium can enter the carbonate lattice since it replaces Ca. This would explain its relatively large variability in terms of concentrations (see Table 3), which relates to the content of $\mathrm{CaO}$, thus producing an $\mathrm{EF} \sim 3$.

The EF values of REEs (up to 3) show a "roof-shaped" pattern (Figure 11), which is generally also recorded in natural waters, minerals and metamorphic and sedimentary rock leachates [86]. Protano and Riccobono [86] identified the same pattern in natural water and sediments of the Noni stream, which is basically a drainage of a mining area from the Colline Metallifere district. Protano and Riccobono [86] recognized the key role of Fe-oxides/oxy-hydroxides in controlling the contents and behavior of REEs in aqueous system. Once in solution, REEs indeed tend to be adsorbed by clay minerals and Fe-Mn-oxides and display enrichments in LREEs, MREEs or HREE depending on the rock source and chemical-physical conditions [87]. The vertical distributions of REE of the studied samples are similar to those of $\mathrm{Al}_{2} \mathrm{O}_{3}$ and $\mathrm{Fe}_{2} \mathrm{O}_{3}$ (Figures 6 and 7). This further suggests that REEs can be hosted into clay minerals and Fe-Mn- oxides. The slight positive Eu anomaly and the moderate enrichment of LREEs with respect to HREEs reflect the presence of primary minerals such as feldspars (in reducing conditions $\mathrm{Eu}^{2+}$ easily replaces $\mathrm{Ca}^{2+}$ in the plagioclase lattice) and monazite, that can be abundant in alluvial environments [88].

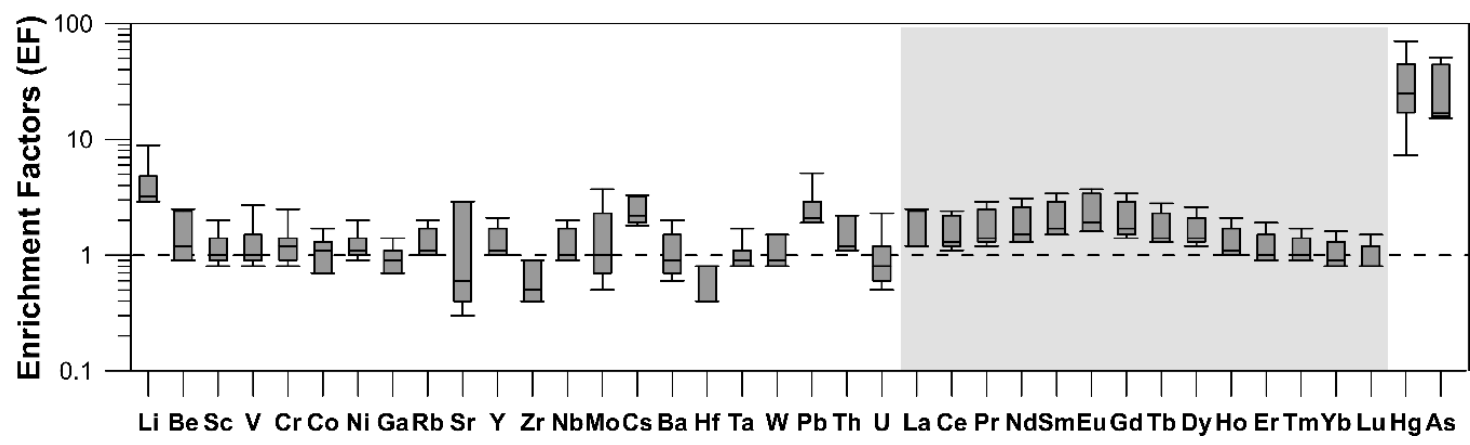

Figure 11. Box and whisker plots for the enrichment factors (EF) for each trace element and Rare Earth Element (REE) (highlighted by gray shadow). The box includes data distributed between the first and third quartile, while the horizontal bar in the box refers to the median value. The ends of the whiskers are the maximum and minimum values. Soil and sediment samples are examined together for the low number of data. The total number of data points used to build each box plot is 7 . The $Y$-axis is logarithmic (Log base 10).

\subsection{Mercury and Arsenic}

Total Hg (0.2-2.7 mg/kg) and As (15.8-44.9 mg/kg) showed anomalously high concentrations, when compared to the average contents of the UCC $(0.05$ and $1.5 \mathrm{mg} / \mathrm{kg}$ for Hg and As, respectively [72,89]) reaching EF values $>40$ (Figure 11). Clearly, southern Tuscany presents a geochemical natural baseline for these elements higher than the UCC, valued in $0.2-0.3 \mathrm{mg} / \mathrm{kg}$ for $\mathrm{Hg}[33,90]$ and $7 \mathrm{mg} / \mathrm{kg}$ for As [84]. 
If the $\mathrm{Hg}$ and As concentrations determined in this study are compared with the southern Tuscany baseline mentioned above, the EFs notably decrease, reaching values of about 4 (moderate enrichment) for both $\mathrm{Hg}$ and As. Nevertheless, considering the catchment geology, the subsurface position of the samples and the absence of anthropogenic evidences in the studied sections, the detected anomalies can reasonably be due to natural sources.

Since the highest contents of As are found in the LU1 sediment samples (coastal beach mainly fed by the sediments of the Albegna river), As is probably sourced by the river-alluvial system and thus by the polymetallic sulfides deposits present in the catchment [65], along with nearshore processes that may have concentrated this element in the littoral sands. The vertical distribution of As (Figure 9) is similar to that of $\mathrm{Fe}_{2} \mathrm{O}_{3}$ (Figure 7), suggesting that As is likely controlled by Fe-oxides. Moreover, the contents of As detected in this study are in agreement with the values found by Sarti et al. [45] in the Holocenic beach sands collected along the southern Tyrrhenian coast and attributed to natural sources. The vertical distribution of $\mathrm{Hg}$ for the sediment samples (Figure 9) is comparable to that of $\mathrm{TiO}_{2}$ (Figure 7). This may indicate that $\mathrm{Hg}$ tends to be enriched in clastic materials (small fragments of cinnabar were found in section A, S. Bianchi, pers. comm.) underling the natural origin from cinnabar mineralization [26]. The slight enrichment of $\mathrm{Hg}$ in soil samples can be due to its preferential distribution in the finer gran-size fractions [91], as also suggested by the relatively high content of $\mathrm{Hg}$ on the fraction $<0.25 \mathrm{~mm}$ with respect to that $<2 \mathrm{~mm}$ (ORB2).

The general low percentages of leached $\mathrm{Hg}$ and As (less than $3 \%$ ) indicate that $\mathrm{Hg}$ and As are hosted in either scarcely soluble minerals (e.g., cinnabar have solubility of $6.4 \times 10^{-53}$ ) or strongly adsorbed/complexed. Nevertheless, the leachable concentrations (0.6-9.7 $\mu \mathrm{g} / \mathrm{L}$ for $\mathrm{Hg}$ and 2.1-36.7 $\mu \mathrm{g} / \mathrm{L}$ for As) are rather high, especially for mercury, when compared to the Italian limits for groundwater: $1 \mu \mathrm{g} / \mathrm{L}$ for $\mathrm{Hg}$ and $10 \mu \mathrm{g} / \mathrm{L}$ for As (D.Lgs. 152/2006). This means that meteoric water could transfer these elements to the main local aquifer (Calcare Cavernoso Fm.). Consequently, Quaternary sediments could be a source of mercury to groundwater system, likely explaining the mercury and, to a minor extent, arsenic anomalies recorded in groundwater of the Ansedonia area [51-54]. Furthermore, considering the "nugget effect" (heterogeneous distribution) of mercury [92], the presence of even Hg-richer sediments cannot be excluded. It can also be speculated that run-off process can transport $\mathrm{Hg}$ - and As-bearing clastic materials in the Orbetello Lagoon, which is the final surface water receptor in the area, contributing to the anomalies also detected into this peculiar ecosystem [46-50].

The results of this study indicate that sedimentological, mineralogical and geochemical features of the Late Pleistocene succession of sediments and soils/paleosols are essentially related to the local geological features and the Quaternary geological history of the area. Therefore, the $\mathrm{Hg}$ and As anomalies detected in the succession, along with other minor trace (e.g., Pb, Li, Mo and Cs) and REEs anomalies, are inferred to natural sources rather than anthropogenic contamination and/or past mining activities. The strikingly high $\mathrm{Hg}$ and As contents detected in this study with respect to the suggested baseline for southern Tuscany highlight the great natural variability that can be present in largely mineralized area. Weathering and redistribution processes could have been very intense during the warmer interglacial MIS5 enhancing the dispersion of mineralization and trace elements associated with them in different components. This result remarks the importance of contributing to the knowledge of geogenic anomalies, to avoid ambiguous interpretations of measured metal contents and promote the adoption of correct management operations by the regulatory agencies. Leaching test results denoted a relatively low mobility of $\mathrm{Hg}$ and As indicating that these elements can be preferentially mobilized by transport of clastic sediments rather than chemical transport in solution. As a consequence, these anomalies may be preserved for relatively long times in the Quaternary sediments. According to the present study, Quaternary successions represent important archives able to record not only significant local and/or regional-to-global geological events, but they are suitable to estimate reference environmental parameters. In particular, the effects of the anthropological pressure or peculiar geogenic anomalies due to presence of specific mineralized deposits can be evidenced by detailed sedimentological, mineralogical and geochemical investigations as those carried out in this 
work. However, leaching test results also revealed that leachable concentrations can be significant when compared to the Italian limit for groundwater, indicating that Quaternary sediment could be a potential, though natural, source of $\mathrm{Hg}$ and As to groundwater systems. Considering the harmfulness and toxic effect of these elements, an adequate monitoring network, both temporally and spatially, of the local main aquifer is thus advisable.

\section{Conclusions}

The extensive sedimentological, mineralogical and geochemical investigations carried out in two Quaternary successions of sediments and soils/paleosols related to the Late Pleistocene of the Ansedonia area (Tuscany, Italy) have unequivocally demonstrated the absence of any anthropogenic activity. Consequently, the studied samples are to be regarded as good proxies for evaluating the geochemical baseline of the metallogenic district of southern Tuscany before the intense exploitation of the ore deposits that occurred for about 3000 years and more importantly before the industrial revolution when the demand of raw materials started to dramatically increase. While the concentrations of major and trace (including REEs) elements did not show any evident enrichment when compared to those of UCC and PAAS, mercury and arsenic resulted significantly higher, with enrichment factors up to $>40$. These results should further be confirmed by additional studies in similar or even more recent sedimentological sections from the northern and southern part of the Albegna river, whose alluvial deposits are fed by sulfide-bearing mineralized areas. This aspect is particularly important because these deposits can be the source of contamination of the local aquifers, as shown by the leaching tests carried out in the present study.

Supplementary Materials: The following are available online at http://www.mdpi.com/2073-4441/12/7/1998/s1, Table S1: Grain size distribution, Table S2: Chemical composition of the studied samples (wt\%), Table S3: Concentrations of trace and rare earth elements $(\mathrm{mg} / \mathrm{kg})$.

Author Contributions: Conceptualization, F.P., O.V. and G.Z.; methodology, F.P., O.V. and G.Z.; software, F.P., and O.V.; validation, F.P., O.V., G.Z. and B.N.; formal analysis, F.P., O.V., G.Z., M.L., M.B., and D.M.; investigation, F.P., O.V., G.Z., M.L., and M.B.; resources, O.V., G.Z., M.L., and M.B.; data curation, F.P., writing original draft preparation, F.P., O.V., and G.Z.; writing-review and editing, B.N., M.B., M.L., D.M.; visualization, F.P.; supervision, O.V. and G.Z.; project administration, O.V., G.Z.; funding acquisition, O.V. All authors have read and agreed to the published version of the manuscript.

Funding: This research received no external funding.

Acknowledgments: Stefano Mirri and Marco Saulo Nannucci (Tuscany Region) are gratefully acknowledged for the useful discussions about the mercury contamination in the Orbetello area. We wish to thank Stefano Bianchi (Studio Tecnico di Geologia e Arte Mineraria, GR), Christian Guidi and the staff of "Il Vigneto" fishing farm (GR) for their help during the field activity.

Conflicts of Interest: The authors declare no conflict of interest.

\section{References}

1. Burgess, N.M. Mercury in Biota and Its Effect. In Mercury: Sources, Cycles and Effects; Parsons, M.B., Percival, J.B., Eds.; Mineralogical Association of Canada: Halifax, NS, Canada, 2005; pp. 235-258.

2. Takizawa, Y. Epidemiology of Mercury Poisoning. In The Biogeochemistry of Mercury in the Environment; Nriagu, J.O., Ed.; Elsevier/North-Holland Biomedical Press: Amsterdam, The Netherlands, 1979; pp. 325-366.

3. Nriagu, J.O. Legacy of Mercury Pollution. Nature 1993, 363-589. [CrossRef]

4. Duker, A.A.; Carranza, E.J.M.; Hale, M. Arsenic Geochemistry and Health. Environ. Int. 2005, 31, 631-641. [CrossRef]

5. Mandal, B.K.; Suzuki, K.T. Arsenic Round the World: A Review. Talanta 2002, 58, 201-235. [CrossRef]

6. Morgan, H.; De Búrca, R.; Martin, I.; Jeffries, J. Soil Guideline Values for Mercury in Soil; Environment Agency: Bristol, UK, 2009.

7. Lamborg, C.H.; Bowman, K.; Hammerschmidt, C.; Gilmour, C.; Munson, K.M.; Selin, N.; Tseng, C.M. Mercury in The Anthropocene Ocean. Oceanography 2014, 27, 76-87. [CrossRef] 
8. Selin, N.E. Global Biogeochemical Cycling of Mercury: A Review. Annu. Rev. Environ. Resour. 2009, 34, 43-63. [CrossRef]

9. Fitzgerald, W.F.; Lamborg, C.H. Geochemistry of Mercury in the Environment. In Treatise on Geochemistry; Sherwood Lollar, B., Holland, H., Turekian, K., Eds.; Elsevier Ltd.: Amsterdam, The Netherlands, 2003; Volume 9, pp. 107-148. [CrossRef]

10. Smedley, P.L.; Kinniburgh, D.G. A Review of the Source, Behaviour and Distribution of Arsenic in Natural Waters. Appl. Geochem. 2002, 17, 517-568. [CrossRef]

11. Reimann, C.; Matschullat, J.; Birke, M.; Salminen, R. Arsenic Distribution in the Environment: The Effects of Scale. Appl. Geochem. 2009, 24, 1147-1167. [CrossRef]

12. Gosar, M.; Pirc, S.; Bidovec, M. Mercury in the Idrijca River Sediments as a Reflection of Mining and Smelting Activities of the Idrija Mercury Mine. J. Geochem. Explor. 1997, 58, 125-131. [CrossRef]

13. Rytuba, B.J.J.; Kotlyar, B.B.; Wilkerson, G.; Olson, J. Geochemistry of Selected Mercury Mine-Tailings in the Parkfield Mercury District, California. In USGS Open-File Reports; U.S. Geological Survey: California, CA, USA, 2001.

14. Gray, J.E.; Hines, M.E.; Higueras, P.L.; Adatto, I.; Lasorsa, B.K. Mercury Speciation and Microbial Transformations in Mine Wastes, Stream Sediments, and Surface Waters at the Almadén Mining District, Spain. Environ. Sci. Technol. 2004, 38, 4285-4292. [CrossRef]

15. Rimondi, V.; Gray, J.E.; Costagliola, P.; Vaselli, O.; Lattanzi, P. Concentration, Distribution, and Translocation of Mercury and Methylmercury in Mine-Waste, Sediment, Soil, Water, and Fish Collected near the Abbadia San Salvatore Mercury Mine, Monte Amiata District, Italy. Sci. Total Environ. 2012, 414, 318-327. [CrossRef]

16. Kulikova, T.; Hiller, E.; Jurkovič, L'; Filová, L.; Šottník, P.; Lacina, P. Total Mercury, Chromium, Nickel and Other Trace Chemical Element Contents in Soils at an Old Cinnabar Mine Site (Merník, Slovakia): Anthropogenic versus Natural Sources of Soil Contamination. Environ. Monit. Assess. 2019, 191. [CrossRef] [PubMed]

17. Piatak, N.M.; Seal, R.R.; Hammarstrom, J.M. Mineralogical and Geochemical Controls on the Release of Trace Elements from Slag Produced by Base- and Precious-Metal Smelting at Abandoned Mine Sites. Appl. Geochem. 2004, 19, 1039-1064. [CrossRef]

18. Garcia-Sanchez, A.; Alvarez-Ayuso, E. Arsenic in Soils and Waters and Its Relation to Geology and Mining Activities (Salamanca Province, Spain). J. Geochem. Explor. 2003, 80, 69-79. [CrossRef]

19. Costagliola, P.; Benvenuti, M.; Benvenuti, M.G.; Innocenti, A.; Mascaro, L.; Paolieri, M.; Rossato, L.; Tanelli, G. Arsenic Distribution in the Quaternary Sediments of the Median Valley of the Pecora Stream (Grosseto, Italy). Brownfield Sites II Assess. Rehabil. Dev. 2004, 201-209. [CrossRef]

20. Dini, A. Ore Deposits, Industrial Minerals and Geothermal Resources. Period. Mineral. 2003, 72, 41-52.

21. Ferrara, R.; Maserti, B.E.; Mazzolai, B.; Di Francesco, F.; Edner, H.; Svanberg, S.; Wallinder, E. Atmospheric Mercury in Abandoned Mine Structures and Restored Mine Buildings at Mt. Amiata, Italy. In Mercury Contaminated Sites. Environmental Science; Ebinghaus, R., Turne, R.R.R., De Lacerda, L.D., Vasiliev, O., Salomons, W., Eds.; Springer: Berlin/Heidelberg, Germany, 1999; pp. 249-257. [CrossRef]

22. Strappa, O. Storia Delle Miniere Di Mercurio Del Monte Amiata. L'Industria Mineraria 1977, 28, $252-439$.

23. Cipriani, C.; Tanelli, G. Risorse Minerarie Ed Industria Estrattiva in Toscana. Atti e Memorie dell'Accademia Toscana di Scienze e Lettere "La Colombaria" 1983, 48, 1-4.

24. Zifferero, A. Miniere e Metallurgia Estrattiva in Etruria Meridionale: Per Una Lettura Critica Di Alcuni Dati Archeologici e Minerari. Stud. Etruschi 1991, 57, 201-241.

25. Dini, A. Miniere e Minerali Del Distretto Mercurifero Del Monte Amiata. In Il Vulcano di Monte Amiata; Principe, C., Lavorini, G., Vezzoli, L., Eds.; ESA: Nola, LA, USA, 2017; pp. 343-369.

26. Arisi Rota, F.; Brondi, A.; Dessau, G.; Franzini, M.; SMMA; SMS; Stea, B.; Vighi, L. I Giacimenti MinerariGiacimenti Dell'area Del Mt. Amiata. In La Toscana Meridionale; Succ. Fusi: Pavia, Italy, 1971; pp. 442-501.

27. Puxeddu, M. Structure and Late Cenozoic Evolution of the Upper Lithosphere in Southwest Tuscany (Italy). Tectonophysics 1984, 101, 357-382. [CrossRef]

28. Peccerillo, A.; Conticelli, S.; Manetti, P. Petrological Characteristics and the Genesis of the Recent Magmatism of Southern Tuscany and Northern Latium. Period. Mineral. 1987, 56, 157-172.

29. Arisi Rota, F.; Vighi, L. Le Mineralizzazioni a Pirite Ed a Solfuri Misti Della Toscana Meridionale. In La Toscana Meridionale; Succ. Fusi: Pavia, Italy, 1971; pp. 368-423. 
30. Tanelli, G.; Lattanzi, P. Pyritic Ores of Southern Tuscany, Italy. In International Congress on Applied Mineralogy, ICAM 81; De Villiers, J., Cawthorn, P., Eds.; Special Publication, Geological Society of South Africa: Johannesburg, South Africa, 1983; pp. 315-323.

31. Cortecci, G.; Klemm, D.D.; Lattanzi, P.; Tanelli, G.; Wagner, J. A Sulfur Isotope Study on Pyrite Deposits of Southern Tuscany, Italy. Miner. Depos. 1983, 18, 285-297. [CrossRef]

32. Benvenuti, M.; Mascara, I.; Corsini, F.; Lattanzi, P.; Parrini, P.; Tanelli, G. Mine Waste Dumps and Heavy Metal Pollution in Abandoned Mining District of Boccheggiano (Southern Tuscany, Italy). Environ. Geol. 1997, 30, 238-243. [CrossRef]

33. Dall'Aglio, M.; Da Roit, R.; Orlandi, C.; Tonani, F. Prospezione Geochimica Del Mercurio. L'Industria Mineraria 1966, 17, 391-398.

34. Ferrara, R.; Maserti, B.E.; Breder, R. Mercury in Abiotic and Biotic Compartments of an Area Affected by a Geochemical Anomaly (Mt. Amiata, Italy). Water Air Soil Pollut. 1991, 56, 219-233. [CrossRef]

35. Cossa, D.; Coquery, M. The Mediterranean Mercury Anomaly, a Geochemical or a Biologocal Issue. In The Mediterranean Sea; Saliot, A., Ed.; Springer: Berlin/Heidelberg, Germany, 2005; pp. 177-208. [CrossRef]

36. Rimondi, V.; Chiarantini, L.; Lattanzi, P.; Benvenuti, M.; Beutel, M.; Colica, A.; Costagliola, P.; Benedetto, F.D.; Gabbani, G.; Gray, J.E.; et al. Metallogeny, Exploitation and Environmental Impact of the Mt. Amiata Mercury Ore District (Southern Tuscany, Italy). Ital. J. Geosci. 2015, 134, 323-336. [CrossRef]

37. Vaselli, O.; Nisi, B.; Rappuoli, D.; Bianchi, F.; Cabassi, J.; Venturi, S.; Tassi, F.; Raco, B. Geochemical Characterization of the Ground Waters from the Former Hg-Mining Area of Abbadia San Salvatore (Mt. Amiata, Central Italy): Criticalities and Perspectives for the Reclamation Process. Ital. J. Geosci. 2015, 134, 304-322. [CrossRef]

38. Vaselli, O.; Higueras, P.; Nisi, B.; María Esbrí, J.; Cabassi, J.; Martínez-Coronado, A.; Tassi, F.; Rappuoli, D. Distribution of Gaseous Hg in the Mercury Mining District of Mt. Amiata (Central Italy): A Geochemical Survey Prior the Reclamation Project. Environ. Res. 2013, 125, 179-187. [CrossRef]

39. Baroni, F.; Boscagli, A.; Di Lella, L.; Protano, G.; Riccobono, F. Arsenic in Soil and Vegetation of Contaminated Areas in Southern Tuscany (Italy). J. Geochem. Explor. 2004, 81, 1-14. [CrossRef]

40. Benvenuti, M.; Mascaro, I.; Corsini, F.; Costagliola, P.; Parrini, P.; Tanelli, G.; Lattanzi, P. Environmental Problems Related to Sulfide Mining in Tuscany. Chron. Rech. Minière 1999, 534, 29-45.

41. Mascaro, I.; Benvenuti, M.; Corsini, F.; Costagliola, P.; Lattanzi, P.; Parrini, P.; Tanelli, G. Mine Wastes at the Polymetallic Deposit of Fenice Capanne (Southern Tuscany, Italy). Mineralogy, Geochemistry, and Environmental Impact. Environ. Geol. 2001, 41, 417-429. [CrossRef]

42. Costagliola, P.; Benvenuti, M.; Chiarantini, L.; Bianchi, S.; Di Benedetto, F.; Paolieri, M.; Rossato, L. Impact of Ancient Metal Smelting on Arsenic Pollution in the Pecora River Valley, Southern Tuscany, Italy. Appl. Geochem. 2008, 23, 1241-1259. [CrossRef]

43. Singh, M.; Müller, G.; Singh, I.B. Geogenic Distribution and Baseline Concentration of Heavy Metals in Sediments of the Ganges River, India. J. Geochem. Explor. 2003, 80, 1-17. [CrossRef]

44. Costagliola, P.; Benvenuti, M.M.; Benvenuti, M.G.; Di Benedetto, F.; Lattanzi, P. Quaternary Sediment Geochemistry as a Proxy for Toxic Element Source: A Case Study of Arsenic in the Pecora Valley (Southern Tuscany, Italy). Chem. Geol. 2010, 270, 80-89. [CrossRef]

45. Sarti, G.; Sammartino, I.; Amorosi, A. Geochemical Anomalies of Potentially Hazardous Elements Reflect Catchment Geology: An Example from the Tyrrhenian Coast of Italy. Sci. Total Environ. 2020, 714, 136870. [CrossRef]

46. Focardi, S. Caratterizzazione Ecotossicologica Dei Sedimenti e Degli Organismi Della Laguna Di Orbetello; University of Siena: Siena, Italy, 2003.

47. Focardi, S. Relazione Tecnico Scientifica Relativa Alla Caratterizzazione Ambientale Dell'area Ex-Sitoco Perimetrazioe a Mare; University of Siena: Siena, Italy, 2005.

48. Aa. Vv. Piano Di Indagini Finalizzato Alla Bonifica Ed Al Risanamento Ambientale Della Laguna Di Orbetello; ICRAM and University of Siena: Rome, Italy, 2008.

49. ISPRA. Interventi per Il Risanamento Delle Aree Lagunari Di Orbetello-Laguna Di Levante; ISPRA: Rome, Italy, 2009.

50. ISPRA. Interventi per Il Risanamento Delle Aree Lagunari Di Orbetello-Laguna Di Ponente; ISPRA: Rome, Italy, 2009. 
51. Grassi, S.; Netti, R. Sea Water Intrusion and Mercury Pollution of Some Coastal Aquifers in the Province of Grosseto (Southern Tuscany-Italy). J. Hydrol. 2000, 237, 198-211. [CrossRef]

52. Protano, G.; Riccobono, F.; Sabatini, G. Does Salt Water Intrusion Constitute a Mercury Contamination Risk for Coastal Fresh Water Aquifers? Environ. Pollut. 2000, 110, 451-458. [CrossRef]

53. Salleolini, M.; Sandrelli, F.; Biserni, G.; Marchetti, M.R.; Nocchi, M.; Focardi, S.; Protano, G.; Pizzetti, E.; Bianchi, S.; Fanciulletti, F. Studio Idrogeologico Finalizzato Alla Simulazione Degli Effetti Dell'emungimento Delle Acque Sotterranee Da Parte Degli Allevamenti Ittici Dell'area Orbetellana e Di Ansedonia. Relazione Finale; Volume A, Univesity of Siena and Giano Ambiente srl: Siena, Italy, 2005.

54. Salleolini, M.; Marchetti, M.R.; Nocchi, M.; Geol, D.; Bianchi, S.; Fanciulletti, F.; Tonelli, D. Studio Geologico, Idrogeologico e Idrogeochimico Finalizzato Alla Valutazione Dell'intrusione Salina Negli Acquiferi Della Zona Costiera Compresa Fra Il Fiume Osa e Il Lago Di Burano_Relazione Finale; University of Siena and Giano Ambiente srl: Siena, Italy, 2009.

55. Bombelli, V.; Lenzi, M. Italy-The Orbetello Lagoon and the Tuscan Coast. In Marine Benthic Vegetation: Recent Changes and the Effects of Eutrophication; Schramm, W., Nienhuis, P.H., Eds.; Springer: Berlin/Heidelberg, Germany, 1996; pp. 331-337. [CrossRef]

56. Tanelli, G. Mineralizzazioni Metallifere e Minerogenesi Della Toscana. Mem. Della Soc. Geol. Ital. 1983, 25, 91-109.

57. Peel, M.; Finlayson, B.; McMahon, T. Update World Map of the Köppen-Geiger Climate Classification. Hydrol. Earth Syst. Sci. 2007, 11, 1633-1644. [CrossRef]

58. Carmignani, L.; Kligfield, R. Crustal Extension in the Northern Apennines: The Transition from Compression to Extension in the Alpi Apuane Core Complex. Tectonics 1990, 9, 1275-1303. [CrossRef]

59. Brogi, A.; Liotta, D. Highly Extended Terrains, Lateral Segmentation of the Substratum, and Basin Development: The Middle-Late Miocene Radicondoli Basin (Inner Northern Apennines, Italy). Tectonics 2008, 27, 1-20. [CrossRef]

60. Signorini, R. Note Illustrative Foglio 135-Orbetello; Poligrafica \& Cartevalori Ercolano (NA): Napoli, Italy, 1967.

61. Pandeli, E.; Bertini, G.; Orti, L. Inquadramento Geologico Regionale Dell'area Del Monte Amiata. In Il Vulcano di Monte Amiata; Principe, C., Lavorini, G., Vezzoli, L.M., Eds.; ESA: Nola, Italy, 2017; pp. 21-54.

62. Federici, P.R.; Mazzanti, R. Note Sulle Pianure Costiere Della Toscana. Mem. Della Soc. Geogr. Ital. 1995, 53, 165-270.

63. Mazzini, I.; Anadon, P.; Barbieri, M.; Castorina, F.; Ferreli, L.; Gliozzi, E.; Mola, M.; Vittori, E. Late Quaternary Sea-Level Changes along the Tyrrhenian Coast near Orbetello (Tuscany, Central Italy): Palaeoenvironmental Reconstruction Using Ostracods. Mar. Micropaleontol. 1999, 37, 289-311. [CrossRef]

64. Coltorti, M.; Ravani, S. Caratteri Geomorfologici Della Fascia Costiera Compresa Tra La Foce Del Fiume Albegna, La Laguna Di Orbetello Ed Ansedonia. In Paesaggi d'Acque, La Laguna di Orbetello e il Monte Argentario tra Preistoria ed Età Romana; Negroni Catacchio, N., Cardosa, M., Dolfini, A., Eds.; Centro Studi di Preistoria e Archeologia, Milano: Milan, Italy, 2017; pp. 48-63.

65. Lattanzi, P. Epithermal Precious Metal Deposits of Italy-an Overview. Miner. Depos. 1999, 34, $630-638$. [CrossRef]

66. Blott, S.J.; Pye, K. GRADISTAT: A Grain Size Distribution and Statistics Package for the Analysis of Unconsolidated Sediments. Earth Surf. Process. Landforms 2001, 26, 1237-1248. [CrossRef]

67. Franzini, M.; Leoni, L.; Saitta, M. Revisione Di Una Metodologia Analitica per Fluorescenza-X, Basata Sulla Correzione Completa Degli Effetti Di Matrice. Rend. Soc. Ital. Miner. Petrol. 1975, 31, 365-378.

68. Lezzerini, M.; Tamponi, M.; Bertoli, M. Reproducibility, Precision and Trueness of X-RAY Fluorescence Data for Mineralogical and/or Petrographic Purposes. Atti della Soc. Toscana Sci. Nat. Mem. Ser. A 2013, 120, 67-73. [CrossRef]

69. Jochum, K.P.; Weis, U.; Schwager, B.; Stoll, B.; Wilson, S.A.; Haug, G.H.; Andreae, M.O.; Enzweiler, J. Reference Values Following ISO Guidelines for Frequently Requested Rock Reference Materials. Geostand. Geoanalytical Res. 2016, 40, 333-350. [CrossRef]

70. Venturi, S.; Vaselli, O.; Rossato, L.; Tassi, F.; Nisi, B.; Pennisi, M.; Cabassi, J.; Bicocchi, G. Anthropogenic Inputs of Boron in the Groundwater System from an Industrial Area near Arezzo (Tuscany, Central Italy). Appl. Geochem. 2015, 63, 146-157. [CrossRef]

71. Soil Survey Staff. Keys to Soil Taxonomy, 12th ed.; USDA: Washington, DC, USA, 2014. 
72. McLennan, S.M. Relationships between the Trace Element Composition of Sedimentary Rocks and Upper Continental Crust. Geochem. Geophys. Geosyst. 2001, 2. [CrossRef]

73. Sawyer, E.W. The Influence of Source Rock Type, Chemical Weathering and Sorting on the Geochemistry of Clastic Sediments from the Quetico Metasedimentary Belt, Superior Province, Canada. Chem. Geol. 1986, 55, 77-95. [CrossRef]

74. Bossio, A.; Foresi, L.M.; Mazzei, R.; Salvatorini, G.; Sandrelli, F.; Bilotti, M.; Colli, A.; Rossetto, R. Geology and Stratigraphy of the Southern Sector of the Neogene Albegna River Basin (Grosseto, Tuscany, Italy). Geol. Rom. 2003, 37, 165-173.

75. Fralick, P.W.; Kronberg, B.I. Geochemical Discrimination of Clastic Sedimentary Rock Sources. Sediment. Geol. 1997, 113, 111-124. [CrossRef]

76. Taylor, S.R.; McLennan, S.M. The Continental Crust: Its Composition and Evolution; Blackwell Scientific Publications: Palo Alto, CA, USA, 1985.

77. Masi, U.; Tucci, P. Geochemical Features of the 'Calcare Cavernoso' from the Monte Argentario Area (Southern Tuscany) and Genetic Implications. Geol. Rom. 1993, 29, 155-161.

78. Feng, R.; Kerrich, R. Geochemistry of Fine-Grained Clastic Sediments in the Archean Abitibi Greenstone Belt, Canada: Implications for Provenance and Tectonic Setting. Geochim. Cosmochim. Acta 1990, 54, 1061-1081. [CrossRef]

79. Wronkiewicz, D.J.; Condie, K.C. Geochemistry of Archean Shales from the Witwatersrand Supergroup, South Africa: Source-Area Weathering and Provenance. Geochim. Cosmochim. Acta 1987, 51, 2401-2416. [CrossRef]

80. Sposito, G. The Chemistry of Soils; Oxford University Press: Oxford, UK, 1989.

81. McLennan, S.M. Weathering and Global Denudation. J. Geol. 1993, 101, 295-303. [CrossRef]

82. Fedoroff, N.; Courty, M.A. Revisiting the Genesis of Red Mediterranean Soils. Turkish J. Earth Sci. 2013, 22, 359-375. [CrossRef]

83. Barbieri, M.; Nigro, A.; Sappa, G. Soil Contamination Evaluation by Enrichment Factor (EF) and Geoaccumulation Index (Igeo). Senses Sci. 2015, 2, 94-97. [CrossRef]

84. Protano, G.; Riccobono, F.; Sabatini, G. La Cartografia Geochimica Della Toscana Meridionale: Criteri Di Realizzazione e Rilevanza Ambientale Attraverso Gli Esempi Di Hg, As, Sb, Pb e Cd. Mem. Descr. Della Cart. Geol. d'Italia 1998, 55, 109-140.

85. Horstman, E. The Distribution of Lithium, Rubidium, and Caesium in Igneous and Sedimentary Rocks. Geochim. Cosmochim. Acta 1957, 12, 1-28. [CrossRef]

86. Protano, G.; Riccobono, F. High Contents of Rare Earth Elements (REEs) in Stream Waters of a Cu-Pb-Zn Mining Area. Environ. Pollut. 2002, 117, 499-514. [CrossRef]

87. Laveuf, C.; Cornu, S. A Review on the Potentiality of Rare Earth Elements to Trace Pedogenetic Processes. Geoderma 2009, 154, 1-12. [CrossRef]

88. Taylor, S.R.; McLennan, S.M. The Significance of the Rare Earths in Geochemistry and Cosmochemistry. In Handbook on the Physics and Chemistry of Rare Earths; Gschneidner, K., Eyring, J., Eyring, L., Eds.; Elsevier Science Publishers B.V.: Norh-Holland, The Netherlands, 1988; Volume 11, pp. 485-578. [CrossRef]

89. Wedepohl, K.H. The Composition of the Continental Crust. Geochim. Cosmochim. Acta 1995, 59, 1217-1232. [CrossRef]

90. Baroni, F.; Protano, G.; Riccobono, F. Mercury Content of the Rocks of Tuscany. Atti Accad. Fisiocratici Siena 1994, 15, 59-67.

91. Ackermann, F. A Procedure for Correcting the Grain Size Effect in Heavy Metal Analyses of Estuarine and Coastal Sediments. Environ. Technol. Lett. 1980, 1, 518-527. [CrossRef]

92. Kocman, D.; Bloom, N.S.; Akagi, H.; Telmer, K.; Hylander, L.; Fajon, V.; Jereb, V.; Jaćimović, R.; Ikingura, J.R.; Horvat, M. Preparation and Characterization of a Soil Reference Material from a Mercury Contaminated Site for Comparability Studies. J. Environ. Manag. 2006, 81, 146-154. [CrossRef]

(C) 2020 by the authors. Licensee MDPI, Basel, Switzerland. This article is an open access article distributed under the terms and conditions of the Creative Commons Attribution (CC BY) license (http://creativecommons.org/licenses/by/4.0/). 